San Jose State University

SJSU ScholarWorks

Master's Theses

Master's Theses and Graduate Research

1999

\title{
Food habits of common dolphin (Delphinus delphis and D. capensis) off California
}

Lizabeth Diane Osnes-Erie

San Jose State University

Follow this and additional works at: https://scholarworks.sjsu.edu/etd_theses

\section{Recommended Citation}

Osnes-Erie, Lizabeth Diane, "Food habits of common dolphin (Delphinus delphis and D. capensis) off California" (1999). Master's Theses. 1892.

DOI: https://doi.org/10.31979/etd.rg6u-uhrz

https://scholarworks.sjsu.edu/etd_theses/1892

This Thesis is brought to you for free and open access by the Master's Theses and Graduate Research at SJSU ScholarWorks. It has been accepted for inclusion in Master's Theses by an authorized administrator of SJSU ScholarWorks. For more information, please contact scholarworks@sjsu.edu. 


\section{INFORMATION TO USERS}

This manuscript has been reproduced from the microfilm master. UMI films the text directly from the original or copy submitted. Thus, some thesis and dissertation copies are in typewriter face, while others may be from any type of computer printer.

The quality of this reproduction is dependent upon the quality of the copy submitted. Broken or indistinct print, colored or poor quality illustrations and photographs, print bleedthrough, substandard margins, and improper alignment can adversely affect reproduction.

In the unlikely event that the author did not send UMI a complete manuscript and there are missing pages, these will be noted. Also, if unauthorized copyright material had to be removed, a note will indicate the deletion.

Oversize materials (e.g., maps, drawings, charts) are reproduced by sectioning the original, beginning at the upper left-hand corner and continuing from left to right in equal sections with small overlaps. Each original is also photographed in one exposure and is included in reduced form at the back of the book.

Photographs included in the original manuscript have been reproduced xerographically in this copy. Higher quality $6^{\prime \prime} \times 9^{n}$ black and white photographic prints are available for any photographs or illustrations appearing in this copy for an additional charge. Contact UMI directly to order.

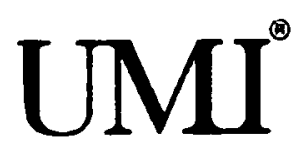

Bell \& Howell Information and Learning 300 North Zeeb Road, Ann Arbor, MI 48106-1346 USA 800-521-0600 


\section{NOTE TO USERS}

This reproduction is the best copy available

\section{UMI}





\title{
FOOD HABITS OF COMMON DOLPHIN
}

(DELPHINUS DELPHIS AND D. CAPENSIS) OFF CALIFORNIA

\author{
A Thesis \\ Presented to \\ The Faculty of Moss Landing Marine Laboratories \\ San Jose State University \\ In Partial Fulfillment \\ of the Requirements for the Degree \\ Master of Science in Marine Science
}

by

Lizabeth Diane Osnes-Erie

August 1999 
UMI Number: 1396193

UMI Microform 1396193

Copyright 1999, by UMI Company. All rights reserved.

This microform edition is protected against unauthorized copying under Title 17, United States Code.

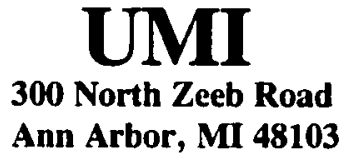


(C) 1999

Lizabeth Diane Osnes-Erie ALL RIGHTS RESERVED 
APPROVED FOR THE DEPARTMENT OF BIOLOGY

Tames T. Nares

Dr. James T. Harvey, Moss Landing Marne Laboratories

Geom. Callie t

Dr. Gregor M. Cailliet, Moss Landing Marine Laboratories

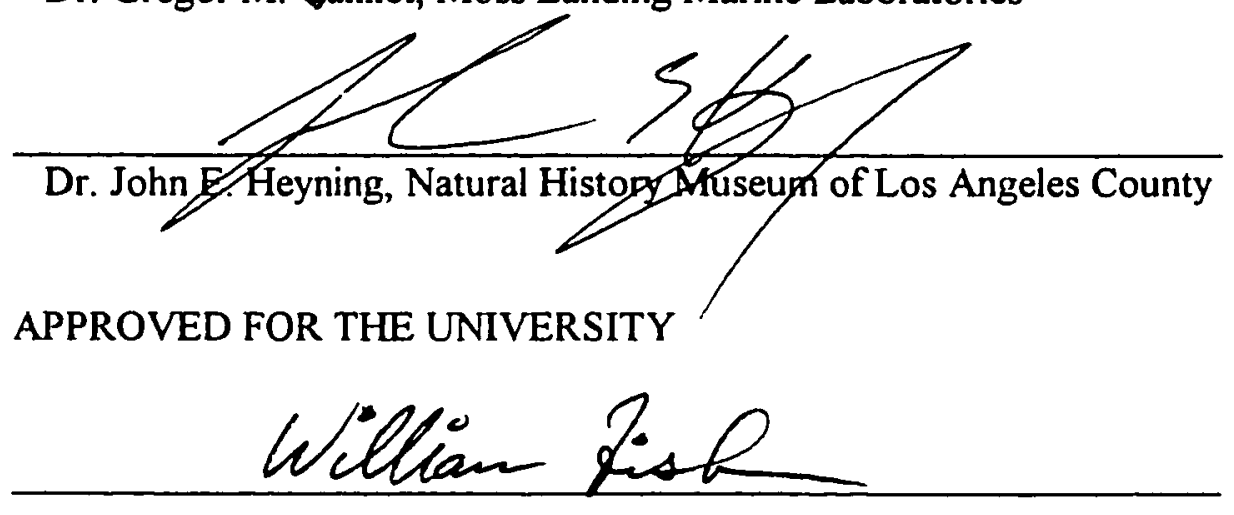




\section{ABSTRACT \\ FOOD HABITS OF COMMON DOLPHIN \\ (DELPHINUS DELPHIS AND D. CAPENSIS) OFF CALIFORNIA}

by Lizabeth Diane Osnes-Erie

Stomach contents of 45 short-beaked (Delphimus delphis) and 49 long-beaked

(Delphimus capensis) common dolphins, collected from 1975 to 1994 off California, were examined from animals killed incidental to fishery operations and stranded specimens.

Short-beaked common dolphin in the by-catch appeared to have different prey species that were important compared to short-beaked common dolphin that had stranded. Longbeaked common dolphin in the by-catch and those that had stranded had similar predominant prey species. Although diets of short-beaked and long-beaked common dolphin in the by-catch appeared statistically similar, they were not similar graphically. Stranded short-beaked and long-beaked common dolphin had similar predominant prey species. Male and female common dolphins of both species had similar diets. Prey species eaten by short-beaked or long-beaked common dolphins were similar among three oceanographic periods. The use of stomach contents from stranded common dolphin to determine "normal" food habits may result in erroneous conclusions. 


\section{ACKNOWLEDGMENTS}

My deepest appreciation goes to my husband and best friend, Scott Erie, whose constant love, encouragement, patience, and financial support were vital to this project. He rarely complained even though he was unable to use the kitchen table for its intended purpose for weeks on end because it was piled high with microscope, vials of otoliths and beaks, reference material, notebooks, computer equipment, etc.

I sincerely thank my committee members, Dr. James Harvey, Dr. Gregor Cailliet, and Dr. John Heyning for their guidance, support, and helpful comments on this manuscript.

I thank the staff at the Natural History Museum of Los Angeles County (especially Dr. John Heyning and Tom Lewis) and the Southwest Fisheries Science Center (especially Dr. Susan Chivers and Kelly Robertson) for loaning me stomach contents of common dolphins. I'm sure they would agree that the stomach contents were returned in a much more user friendly condition than when they were loaned out. I also thank the stranding network participants from Moss Landing Marine Laboratories and Long Marine Lab for assisting in the collection and necropsy of deceased common dolphins. Who will ever forget those wonderful Necropsy Days!

Very special thanks goes to Bill Walker for his invaluable assistance with verification and identification of fish otoliths and cephalopod beaks. It was an extraordinary learning experience. 
Funding from the Dr. Earl and Ethel Myers Oceanographic and Marine Biology Trust, the American Cetacean Society - Monterey Bay Chapter, and the Packard Foundation helped to make this research possible.

Thank you to Alan and Sheila Baldridge for their assistance in obtaining reference materials and for being such wonderful and supportive friends. Alan introduced me to Dr. John Heyning which was the first step in developing this project.

I thank the students, faculty, and staff at Moss Landing Marine Laboratories for providing a place of learning and growing as a person and an unforgetable educational experience. Special thanks goes to Lynn McMasters for help with computer graphics; Gail Johnston with SJSU paperwork; Sheila Baldridge, Joan Parker, and Terry Darcey for obtaining reference materials. Thank you to Tony Orr and Terry Darcey for assistance with questions regarding data analyses and statistics.

I am extremely grateful to my parents, Russ and Ardelle Osnes, for instilling in me the values and independence that have helped me through this process and for their love and support. I also thank Denny and Barb Erie for their love, encouragement, and support.

Special thanks goes to my local "mom", Alpha Myhre, for her support and love. Thanks for the fun times and for being such a wonderful friend.

I thank my "children", Alpha, Omega, Peanut, Andy, Jimmy, and Jasmine, who provided me with comic relief and were always there when I needed them. Thanks for being your furry selves. 
And finally, I thank all the common dolphins who donated their bodies to science so that I could "discover" something about them. I especially enjoyed meeting two live common dolphins. The first, Catalina Bob, who after stranding beat the odds with help from some human friends and is swimming free again. He taught me to never give up even when people seem to be throwing things at you (it just might be something good like a fish) and that things really get going at about 2:00 am in the doiphin world. The second, Cooper, who stranded as a youngster and lives at Sea World of California, taught me that on your way to reaching a goal, put all you have into the journey, with a few twists and turns thrown in for good measure, and your reward will be waiting for you at the end (thank goodness for me it was a Master's degree rather than a fish). 


\section{TABLE OF CONTENTS}

\section{Page}

List of Tables . . . . . . . . . . . . . . . . . . . . ix

List of Figures . . . . . . . . . . . . . . . . . . . . . . $x$

List of Appendices . . . . . . . . . . . . . . . . . . . . . . . . . xi

Introduction . . . . . . . . . . . . . . . . . . 1

Methods . . . . . . . . . . . . . . . . . . 4

Results . . . . . . . . . . . . . . . . . . 8

Discussion . . . . . . . . . . . . . . . . . . . . . . 13

Literature Cited . . . . . . . . . . . . . . . . . . . . 26

Tables . . . . . . . . . . . . . . . . . 34

Figures . . . . . . . . . . . . . . . . . . . . . . . 38

Appendices . . . . . . . . . . . . . . . . . . . . . . . 46 


\section{LIST OF TABLES}

Table

1. Mean prey array indices characterizing the diets of short-beaked (Delphimus delphis) and long-beaked (Delphimus capensis) common dolphins collected in the by-catch and those that had stranded

2. Critical values for Ryan's Q test (with Kramer's modification) for the comparison of prey array indices between short-beaked (Delphimus delphis) and long-beaked (Delphimus capensis) common dolphins collected in the by-catch and those that had stranded off California from 1975 to 1994

3. Estimated standard lengths (SL) of predominant prey species eaten by short-beaked (Delphimus delphis) and long-beaked (Delphinus capensis) common dolphins collected in the by-catch and those that had stranded off California from 1975 to 1994 


\section{LIST OF FIGURES}

Figure $\quad$ Page

1. Locations of specimens of short-beaked (Delphinus delphis) and long-beaked (Delphinus capensis) common dolphins collected in the by-catch and those that had stranded off California from 1975 to 1994

2. Cumulative prey species curves used to determine minimum number of stomach samples needed to adequately describe food habits of short-beaked (Delphinus delphis) and long-beaked (Delphinus capensis) common dolphins collected in the by-catch and those that had stranded off California from 1975 to 1994

3. Two-dimensional Index of Relative Importance (IRI) for:

A) short-beaked common dolphin in the by-catch, B) short-beaked common dolphin that had stranded, C) long-beaked common dolphin in the by-catch, and D) long-beaked common dolphin that had stranded

4. Two-dimensional Index of Relative Importance (IRI) for: A) male short-beaked common dolphin in the by-catch, B) female short-beaked common dolphin in the by-catch, C) male short-beaked common dolphin that had stranded, and D) female short-beaked common dolphin that had stranded

5. Two-dimensional Index of Relative Importance (IRI) for: A) male long-beaked common dolphin and B) female long-beaked common dolphin .

6. Two-dimensional Index of Relative Importance (IRI) for:

A) short-beaked common dolphin in the by-catch (November-February, $\mathrm{n}=12$ ), B) short-beaked common dolphin in the by-catch (March-August, $\mathrm{n}=8$ ), and $\mathrm{C}$ ) short-beaked common dolphin in the by-catch (SeptemberOctober, $n=8$ )

7. Two-dimensional Index of Relative Importance (IRI) for:

A) long-beaked common dolphin (November-February, $n=18$ ),

B) long-beaked common dolphin (March-August, $n=26$ ), and

C) long-beaked common dolphin (September-October, $n=5$ ) . . . . .

8. Two-dimensional Index of Relative Importance (IRI) for:

A) short-beaked common dolphin in the by-catch, B) short-beaked common dolphin that had stranded, C) long-beaked common dolphin in the by-catch, and D) long-beaked common dolphin that had stranded 


\section{LIST OF APPENDICES}

Appendix

Page

1. Specimens obtained of short-beaked (Delphimus delphis) and long-beaked (Delphimus capensis) common dolphins from the Natural History Museum of Los Angeles County (LACM), Southwest Fisheries Science Center (SWFSC), Long Marine Laboratories (LML), and Moss Landing Marine Laboratories (MLML)

2. Mean $\% \mathrm{~N}$, standard deviation (SD), \%FO, IRI, and \%IRI for prey species identified from stomach contents of short-beaked common dolphin in the by-catch $(n=28)$, collected off California from 1983 to 1992

3. Mean $\%$, standard deviation (SD), $\% \mathrm{FO}, \mathrm{IRI}$, and $\% \mathrm{IRI}$ for prey species identified from stomach contents of short-beaked common dolphin that had stranded $(n=17)$, collected off California from 1975 to 1993

4. Mean $\% \mathrm{~N}$, standard deviation (SD), $\% \mathrm{FO}, \mathrm{IRI}$, and $\% \mathrm{IRI}$ for prey species identified from stomach contents of long-beaked common dolphin in the by-catch $(n=14)$, collected off California from 1986 to 1992

5. Mean $\% \mathrm{~N}$, standard deviation (SD), $\% \mathrm{FO}$, IRI, and $\% \mathrm{IRI}$ for prey species identified from stomach contents of long-beaked common dolphin that had stranded $(n=35)$, collected off California from 1978 to 1994 


\section{INTRODUCTION}

The common dolphin, referred herein general to the Genus Delphinus, has a cosmopolitan distribution in tropical and temperate waters. Because of its wide distribution and geographical variation, local morphological variants occasionally were recognized as subspecies or even separate species (Hershkovitz 1966). Although most authorities have recognized one species world-wide, D. delphis (Hershkovitz 1966, Mitchell 1975, Hall 1981), several researchers have identified distinct long-beaked species in some regions, such as D. capensis off West Africa (Ellerman and Morrison-Scott 1951) and in the northeast Pacific Ocean (Heyning and Perrin 1994), and D. tropicalis in the Indian Ocean (Honacki and others 1982).

In the northeast Pacific, two morphologically and genetically distinct species of common dolphin occur sympatrically from central California to at least the tip of Baja California, Mexico (Heyning and Perrin 1994, Rosel and others 1994). The larger, long-beaked common dolphin (Delphimus capensis) occurs within approximately $150 \mathrm{~km}$ of the coast. The smaller, more pelagic, short-beaked common dolphin (Delphinus delphis) occurs from the coast to thousands of kilometers offshore (Heyning and Perrin 1994). Herds of the two species apparently do not mix and have never been collected together (Evans 1982, Heyning and Perrin 1994).

To occur sympatrically and reduce competition, these two species of common dolphin probably exploit the environment in subtly different ways. The long-beaked common dolphin has a longer, more robust jaw and larger teeth than the short-beaked 
common dolphin (Heyning and Perrin 1991), suggesting the two species may consume different prey.

Common dolphin (hereafter the general term common dolphin will infer the two species found off California) feed on a variety of fishes and cephalopods. Known prey species off California include: epipelagic, mesopelagic, and bathypelagic fishes from 13 families including Argentinidae, Bathylagidae, Batrachoididae, Centrolophidae, Engraulidae, Melamphaidae, Merlucciidae, Myctophidae, Ophidiidae, Osmeridae, Sciaenidae, Scomberesocidae, and Scombridae; three squid families including Gonatidae, Loliginidae, and Onychoteuthidae; and crustaceans (Brown and Norris 1956, Norris and Prescott 1961, Fiscus and Niggol 1965, Fitch and Brownell 1968, Evans 1975, Jones 1981).

Only one study has been conducted in which researchers analyzed stomach contents of short-beaked and long-beaked common dolphins separately (Schwartz and others 1992). Gonatid squid (54.5\%) and market squid (Loligo opalescens; $17 \%$ ) were the two most numerous prey items of short-beaked common dolphin. The two most numerous prey species of long-beaked common dolphin were northern anchovy (Engraulis mordax, 50.4\%) and Pacific hake (Merluccius productus, 42.4\%). Schwartz and others (1992) suggested that short-beaked and long-beaked common dolphins fed primarily on different prey items, but due to small and uneven sample sizes, these results were inconclusive.

Few researchers also have compared food habits between delphinids caught as 
by-catch in a fishery and delphinids that had stranded (Leatherwood and others 1978, Barros and Odell 1990). Dolphins found stranded are likely to include a high proportion of animals that were sick and had not fed normally immediately before death (Pierce and Boyle 1991). Schwartz and others (1992) noted that the more pelagic cetacean species may take longer to strand, and if prey remains were recovered, they would likely be of near-shore prey species, therefore, atypical. Food items in stomachs of stranded animals, therefore, may not accurately reflect the food habits of healthy animals (Leatherwood and others 1978). Dolphins in the by-catch would be considered "normally" feeding animals.

Schools of common dolphin generally are a mixture of males and females, however, there may be a greater percentage of females to males (Walker 1975). Because common dolphin schools do not appear to be segregated by sex, it is probable that they eat similar prey items.

The seasonal migratory pattern of prey species may influence the food habits of common dolphin because some prey species may be more available to common dolphin at certain times of the year. Evans (1975) found that common dolphin off southern California fed predominantly on northern anchovy and market squid during the fall and winter (September to January) and on bathylagid and myctophid fishes during the spring and summer (March to July). These seasonal differences were based on uneven sample sizes and were not differentiated between short-beaked and long-beaked common dolphin species, therefore, were inconclusive. 
The objectives of this study were to identify prey species from stomach contents of short-beaked and long-beaked common dolphins off California and determine if there were differences in food habits: 1) between the two species; 2) between specimens in the by-catch and specimens that had stranded; 3) between males and females; and 4) among specimens collected during three oceanographic periods [Davidson Current (NovemberFebruary), Upwelling (March-August), and Oceanic (September-October)].

The hypotheses under investigation were as follows: 1) short-beaked common dolphins fed predominantly offshore and ate primarily mesopelagic fishes and squids, whereas, long-beaked common dolphins fed more inshore and ate primarily fishes, such as Pacific hake and northern anchovy, and squid; 2) short-beaked common dolphins that stranded switched from their "normal" diet before stranding and fed predominantly on inshore prey species; 3) male and female common dolphins of the same species consumed similar prey species; and 4) common dolphins did not change their diet among oceanographic periods.

\section{METHODS}

Stomach contents, of common dolphins collected from 1975 to 1994 off California, were examined from animals killed incidental to fishery operations (short-beaked common dolphin, $\mathrm{n}=21$ males, $\mathrm{n}=7$ females; long-beaked common dolphin, $n=3$ males, $n=11$ females) and stranded specimens (short-beaked common dolphin, $n=10$ males, $n=7$ females; long-beaked common dolphin, $n=18$ males, $n=17$ females; Fig. 1). Samples were obtained from the Natural History Museum of Los Angeles County ( $n=57$ ), Southwest Fisheries Science Center ( $n=27$ ), Long Marine Laboratory (U.C. Santa Cruz; 
$\mathrm{n}=1$ ), and Moss Landing Marine Laboratories ( $\mathrm{n}=9$; Appendix 1). Short-beaked common dolphins ranged in size from 124 to $206 \mathrm{~cm}$ standard length and long-beaked common dolphins from 106 to $235 \mathrm{~cm}$.

Collection of stomach contents was opportunistic, therefore, not evenly distributed through the periods. Twenty-four (53\%) short-beaked common dolphin were collected from November to February, 12 (27\%) from March to August, and nine (20\%) from September to October. Eighteen (37\%) long-beaked common dolphin were collected from November to February, 26 (53\%) from March to August, and five (10\%) from September to October.

During dissection, stomachs were tied off at the esophageal and pyloric ends before removal from the animal. Stomachs were opened and the contents were cleaned by flotation and decanting (Jones 1981), rinsed through a $0.5 \mathrm{~mm}$ sieve, emptied into a tray and sorted. Fish otoliths (sagittae), cephalopod beaks, and crustaceans were identified to the lowest taxon possible using reference collections at Moss Landing Marine Laboratories, photographic identifications of otoliths (Fitch 1967, 1968, 1969, Fitch and Brownell 1968), and taxonomic keys of cephalopod beaks (Iverson and Pinkas 1971, Clarke 1986a) and crustaceans (Schmitt 1921, Butler 1980). Prey species identifications were verified or initially identified with the assistance of William A. Walker, National Marine Mammal Laboratory, Seattle.

The minimum number of prey ingested was determined using the greater number of left or right otoliths and upper or lower cephalopod beaks. Fish otoliths were measured with vernier calipers, to the nearest $0.1 \mathrm{~mm}$ length, at the maximum length parallel to the 
sulcus. Otoliths were stored dry in gelatin capsules and glass vials. Cephalopod beaks were measured (lower rostral length of squid, lower hood length of octopus and Rossia pacifica), and stored in 50\% isopropyl alcohol. Otoliths and beaks that were broken or had obvious signs of damage from digestion were not measured. Crustaceans were stored in $50 \%$ isopropyl alcohol.

The cumulative number of prey species was plotted against the cumulative number of stomachs analyzed to determine the minimum number of stomachs needed to adequately describe food habits of short-beaked and long-beaked common dolphins that were in the by-catch or had stranded. The order in which stomachs were analyzed was randomized five times and the mean number of new prey species plotted against the number of stomachs analyzed. One standard deviation also was plotted for every fifth stomach.

Traditional methods of assessing food habit data are percentage number, percentage frequency of occurrence, and percentage volume. The well-digested state of many of the stomach samples used in the present study prevented direct volumetric estimation, and regression equations for determination of prey weight were lacking for many species. Samples were analyzed, therefore, using percentage frequency of occurrence $(\% \mathrm{FO})$ and mean percentage number $(\% \mathrm{~N})$.

Mean $\% \mathrm{~N}$ of prey items identified to species level was used to calculate several standard diet indices (see Krebs 1989) for short-beaked and long-beaked common dolphins that were in the by-catch or had stranded to allow comparison between groups. 
These indices were:

Species richness $(\mathbf{S})=$ number of prey species

Shannon-Weiner diversity index $\left(\mathrm{H}^{\prime}\right)=\Sigma\left(\mathrm{p}_{\mathrm{i}}^{*} \ln \mathrm{p}_{\mathrm{i}}\right)$

Niche Breadth $(B)=(1 / D)$,

Prey Evenness $(J)=H^{\prime} / H^{\prime}{ }_{\max }$, where $\mathrm{H}^{\prime}{ }_{\max }=\ln \mathrm{S}$

Index of Specialization $(R)=1-J$

Prey Dominance $(D)=\Sigma \mathrm{pi}^{2}$

where $p_{i}$ is the proportion of each prey item in the sample (stomach). One-way Analysis of Variances (ANOVA) were used to determine if mean species richness, prey diversity, niche breadth, evenness, specialization, or dominance differed significantly among the four dolphin groups (short-beaked in the by-catch, short-beaked that had stranded, long-beaked in the by-catch, and long-beaked that had stranded). Prey indices met the test for equal variance and normality except for species richness. After species richness data were log transformed they met the test for equal variance and normality and an ANOVA was run on the transformed data. Because there were unequal sample sizes, pairwise comparisons using the Kramer modification of Ryan's Q test (Day and Quinn 1989) were conducted to determine which means differed.

Percentage FO and mean $\% \mathrm{~N}$ were determined for each prey species within each of the four common dolphin groups. Two dimensional indices of relative importance (IRI; Laroche 1982 , Govoni and others 1983 ) were calculated by multiplying \%FO by mean $\%$ N. Total IRI values were then expressed as \%IRI (IRI for each prey item divided by the sum of the IRI values for all prey items in that dolphin group) to allow for determination of prey item importance. 
Spearman's rank correlation was used to measure differences in rank orders of \%IRI of prey species utilized by short-beaked and long-beaked common dolphins. Percentage IRI determinations included only those prey items identified to species level. Correlation coefficients have both desirable and undesirable attributes (Krebs 1989). They are completely insensitive to additive or proportional differences between community samples, but strongly affected by sample size, especially in high-diversity communities. Field (1970) recommended that, when more than half of the abundances are zero in a community sample, the correlation coefficient should not be used as a measure of similarity. The top ranked six to eight prey items for each dolphin group, therefore, were used in analyses to prevent prey species that irregularly occurred from changing statistical significance results in a non-meaningful way. Comparisons were made: 1) between short-beaked and long-beaked common dolphins; 2) within each species for specimens in the by-catch and specimens that had stranded; 3) between males and females for each species; and 4) among three oceanographic periods for each species. A 0.05 level of significance was used to test the null hypothesis and power of the statistical tests, the probability of correctly rejecting the null hypothesis, was determined if not significant and $n \geq 10($ Zar 1984)

The estimated maximum, minimum, and average length for prey species were calculated using regressions of fish standard length (SL) to otolith length (OL; Harvey and others in press) and cephalopod mantle length (ML) to lower rostral length or lower hood length (Clarke 1986a) for species in which values had been determined. Rockfish (Sebastes sp.) otoliths most closely resembled bocaccio (Sebastes paucispinis), therefore, 
the length regression equation for that species was used. For cephalopod species where regressions were unavailable, the genus or family length equations were used.

\section{RESULTS}

Stomach contents of all 94 common dolphin specimens were examined and contained a combined total of 16,384 fish otoliths and 6,565 cephalopod beaks. Forty-nine fish species, representing 26 families, 18 cephalopod species, representing 11 families, and one crustacean species were identified as prey among the four dolphin groups. Of these, 32 species of fish, 11 species of cephalopods, and one species of crustacean had not been reported previously as prey of common dolphin (Appendix 2-5). Only $0.9 \%$ of otoliths and $0.1 \%$ of beaks were not identifiable.

The greatest number of prey was found in a $178-\mathrm{cm}$ male short-beaked common dolphin from the by-catch (LACM 86087). Prey hard parts represented 1,098 individuals, $633(58 \%)$ of which were myctophids and $218(20 \%)$ were the squid, Abraliopsis felis. The greatest number of prey found in a long-beaked common dolphin that had stranded (235 cm TL, male, LACM 88997) was 259 individuals, 239 (92\%) of which were Pacific hake. The average length of Pacific hake eaten by this dolphin was $16.75 \mathrm{~cm}(\mathrm{SE}=0.11)$ with an average weight of $35.68 \mathrm{~g}(\mathrm{SE}=0.83)$.

Cumulative species curves gradually reached an asymptote, with one exception for long-beaked common dolphin in the by-catch (Fig. 2). The asymptotes reached, as well as the narrowing of the standard errors, by short-beaked common dolphin and long-beaked common dolphin that had stranded suggest that a sufficient number of stomachs were collected to adequately assess the number of species eaten. Long-beaked common dolphin 
in the by-catch did not reach an asymptote indicating that a sufficient number of stomachs for that group was not collected.

Species richness, prey diversity, and niche breadth were greatest in short-beaked common dolphin in the by-catch and least for long-beaked common dolphin that had stranded (Table 1). There was a significant difference in species richness and prey diversity between common dolphin groups, although no difference between short-beaked that had stranded and long-beaked that had stranded (Table 2). Niche breadth was significantly different between: short-beaked common dolphin in the by-catch and those that had stranded, short-beaked common dolphin in the by-catch and long-beaked common dolphin that had stranded, and long-beaked common dolphin in the by-catch and those that had stranded.

Prey evenness was greatest in short-beaked common dolphin in the by-catch and least in short-beaked common dolphin that had stranded (Table 1), however, there were no significant differences among the four dolphin groups $(P>0.10$, power $=0.30)$. There was no significant difference in prey specialization among the four dolphin groups $(P>0.10$, power $=0.30)$, although prey specialization was greatest in short-beaked common dolphin that had stranded and least in short-beaked common dolphin in the by-catch. Prey dominance was greatest in long-beaked common dolphin that had stranded and least in short-beaked common dolphin in the by-catch, with a significant difference between: short-beaked common dolphin in the by-catch and those that had stranded (Table 2), short-beaked common dolphin in the by-catch and long-beaked common 
dolphin that had stranded, short-beaked common dolphin that had stranded and long-beaked common dolphin in the by-catch, and long-beaked common dolphin in the by-catch and those that had stranded.

There were differences in the number of prey species eaten by each of the four common dolphin groups, however, predominant prey were similar for at least three of the four groups. Short-beaked common dolphin in the by-catch fed on at least 36 fish species ( $81.2 \%$ of diet by \%IRI; Appendix 2) dominated by five species of Myctophidae ( $28 \%$ of diet by \%IRI combined). At least 17 fish species (45.5\% of diet by \%IRI; Appendix 3) were consumed by short-beaked common dolphin that had stranded, dominated by Pacific hake ( $18.6 \%$ of diet by \%IRI). Short-beaked common dolphin in the by-catch fed on a minimum of 16 cephalopod species ( $15.3 \%$ of diet by \%IRI; Appendix 2 ) dominated by A. felis ( $14.8 \%$ of diet by \%IRI), whereas, short-beaked common dolphin that had stranded fed on a minimum of 10 cephalopod species ( $54.5 \%$ of diet by \%IRI; Appendix 3) dominated by market squid ( $17.6 \%$ of diet by $\%$ IRI). Although Pacific hake was the dominant fish species consumed by long-beaked common dolphin in the by-catch $(19.5 \%$ of diet by \%IRI; Appendix 4) and those that had stranded (19.6\% of diet by $\% \mathbb{R I}$; Appendix 5), dolphins in the by-catch ate at least 27 additional fish species ( $76 \%$ of diet by $\%[R I)$, whereas, dolphins that had stranded fed on at least 19 additional fish species ( $61 \%$ of diet by $\% \mathbb{R I}$ ). Long-beaked common dolphin in the by-catch fed on a minimum of 12 cephalopod species ( $24 \%$ of diet by \%IRI; Appendix 4) dominated by market squid (18.6\% of diet by \%IRI), and long-beaked common dolphin that had stranded fed on a 
minimum of 10 cephalopod species ( $39 \%$ of diet by \%IRI, Appendix 5) dominated by market squid ( $17.7 \%$ of diet by \%IRI). Crustaceans made up $3.6 \%$ of diet by $\%$ IRI for short-beaked common dolphin in the by-catch (Appendix 2).

Short-beaked common dolphin in the by-catch had different prey species that were important compared to short-beaked common dolphin that had stranded $\left(r_{\mathbf{s}}=-0.713\right.$, P < 0.01; Fig. 3). Long-beaked common dolphin in the by-catch and those that had stranded had similar predominant prey species $\left(r_{s}=0.133, P>0.50\right.$, power $=0.94 ;$ Fig. 3). Diet of short-beaked and long-beaked common dolphin in the by-catch were not different significantly $\left(r_{\mathrm{s}}=-0.259, P>0.20\right.$, power $=0.88 ;$ Fig. 3$)$. Stranded short-beaked and long-beaked common dolphin had similar predominant prey species $\left(r_{\mathbf{s}}=0.527, P>0.10\right.$, power $=0.62$; Fig. 3) .

Male and female common dolphins of both species had similar diets (Figs. 4-5). There was no significant difference between the diets of male and female short-beaked common dolphin in the by-catch $\left(r_{\mathbf{l}}=-0.188, \mathrm{P}>0.50\right.$, power $\left.=0.93\right)$, male and female short-beaked common dolphin that had stranded $\left(r_{1}=0.219, P>0.50\right.$, power $\left.=0.91\right)$, or male and female long-beaked common dolphin $\left(r_{\mathbf{z}}=0.385, P>0.20\right.$, power $\left.=0.78\right)$.

The diet of short-beaked common dolphin in the by-catch was similar among the three oceanographic periods (Fig. 6). There was no significant difference in the diet of short-beaked common dolphin in the by-catch between November-February and MarchAugust $\left(r_{2}=-0.273, P>0.20\right.$, power $\left.=0.89\right)$, November-February and SeptemberOctober $\left(r_{\mathbf{s}}=-0.195, P>0.50\right.$, power $\left.=0.93\right)$, or March-August and September-October $\left(r_{\mathrm{a}}=-0.209, \mathrm{P}>0.50\right.$, power $\left.=0.91\right)$. Sample sizes of short-beaked common dolphin that 
had stranded were too uneven, only one sample in September-October, to include in the analyses.

Prey species eaten by long-beaked common dolphin also were similar among the three oceanographic periods (Fig 7). There was no significant difference in the diet of long-beaked common dolphin between November-February and March-August $\left(r_{s}=0.212, P>0.50\right.$, power $\left.=0.92\right)$, November-February and September-October $\left(r_{\mathbf{t}}=0.225, P>0.50\right.$, power $\left.=0.91\right)$, or March-August and September-October $\left(r_{\mathbf{s}}=0.134, P>0.50\right.$, power $\left.=0.95\right)$.

Common dolphin of both species ate more fishes than cephalopods, however, the frequency of fishes and cephalopods was similar (Fig. 8). Dolphins in the by-catch ate more fish and fewer cephalopods than dolphins that had stranded.

Both species of common dolphin ate both juvenile and adult fishes and cephalopods (Table 3); however, mean prey sizes indicated that juveniles were eaten the majority of the time. Prey sizes ranged up to $38 \mathrm{~cm}$ but generally were less than $20 \mathrm{~cm}$ in length. Prey of common dolphin can be found throughout the water column; however, $60-70 \%$ of predominant prey inhabited the midwater zone. Over $70 \%$ of predominant prey were vertical migrators, coming near the surface at night. Common dolphins were restricted to prey found within their range of diving depth including animals that live near the surface and vertically migrate.

\section{DISCUSSION}

Food habit studies on marine mammals can provide information on habitat use, niche partitioning, distribution and movement patterns, and marine mammal-fisheries 
interactions, which may be of considerable economic and ecological significance. Studies may involve direct observation, or examination of feces or stomach contents.

There are inherent biases of each food habit study method, including the analysis of stomach contents. Differential rates of digestion and evacuation of different fish species can bias analysis of stomach contents (Hyslop 1980, Harvey 1987, Jobling 1987, Pierce and Boyle 1991). The extent to which erosion of prey hard parts occurs will vary with the degree of acidity in the predator's stomach, the exposure time, and form and structure of the hard parts (Jobling and Breiby 1986). Otoliths with high area/volume ratios (small, flat, and irregularly shaped otoliths) are more likely to be digested than otoliths with low area/volume ratios (Fiscus and Baines 1966, daSilva and Neilson 1985, Murie and Lavigne 1985, Jobling and Breiby 1986). Differential dissolution of otoliths is likely among different fish of the same species, within the same fish (depending on when the otoliths were released from the skull case), and among different species of fish (Murie and Lavigne 1985). Differences in rates of dissolution among otoliths of different prey species could lead to errors regarding the relative importance of different prey species in the diet (Jobling and Breiby 1986). Numbers of fish ingested and fish sizes derived by backcalculation from otolith measurements may be under-estimated (Murie and Lavigne 1985, Jobling and Breiby 1986, Jobling 1987, Pierce and Boyle 1991). In this study, because of dissolution, numbers of individual fish and numbers of fish species may be under-represented and fish sizes may be under-estimated.

Cephalopod beaks are retained longer than fish remains and can accumulate in predator stomachs becoming entrapped in the stomach rugae, exaggerating their 
importance in the diet (Fiscus and Baines 1966, Pitcher 1980, Bigg \& Fawcett 1985, Selzer and others 1986, Gales and Pemberton 1992, Harvey and Antonelis 1994). Ross (1979) determined in bottlenose dolphin (Tursiops aduncus) that otoliths of most fish were digested in less than $\mathbf{4 8}$ hours, however, cephalopod beaks could be retained for three days or more. Stroud and others (1981) found that fragments of prey species may remain in the stomach of cetaceans from 12 to 24 hours after feeding. Passage through the digestive system generally has no visible effect on the appearance of squid beaks (Bigg and Fawcett 1985), therefore, numbers of cephalopods ingested and cephalopod sizes derived by back-calculation from beak measurements should not be under-estimated. In this study, cephalopod beaks may be over-represented because of accumulation. It also is possible that dolphins that had stranded may not have eaten recently, therefore, cephalopod beaks may be over-represented, whereas, otoliths may be under-represented because they may have been digested.

The occurrence of material from the stomachs of the primary prey may be mistaken as food items of the predator and could bias the results of stomach content analysis (Perrin and others 1973, Walker 1981, Harkonen 1986, Pierce and Boyle 1991, Walker and Jones 1993). Isolated otoliths and beaks of small prey could be regarded as potential prey of larger prey ingested (Walker and Jones 1993). Although it is possible that some of the samples from the by-catch animals used in this study contained secondary prey, they probably represented a very small percentage and had little influence, if any, on the results. 
Because this study involved two sympatric dolphin species, it was assumed that biases would affect each species similarly and relative importance of prey species would be comparable in each dolphin group. Correction factors, therefore, were not used and estimates of prey numbers and sizes are considered minimums.

Both short-beaked and long-beaked common dolphins can be affected by fishery interactions. Three fisheries off California that incidentally take/have taken marine mammals include: 1) the nearshore set gillnet fishery, 2) the offshore drift gillnet fishery, and 3) the purse seine fishery (Heyning and others 1994). Heyning and others (1994) found that in 69 fishery-related takes of odontocetes, $44.9 \%(n=31)$ were of common dolphins including 19 long-beaked common dolphin, two short-beaked common dolphin, and 10 unidentified common dolphin. Short-beaked and long-beaked common dolphins were the most frequently caught cetacean species in gill nets south of Pt. Conception, California (Diamond and others 1987). As stated previously, prey hard parts can remain in dolphin stomachs for 12-24 hours, therefore, stomach contents from common dolphins in the by-catch should be representative of day and night feeding. Short-beaked and long-beaked common dolphins should be treated separately with regard to resource management and fishery interactions, therefore, correct species identification is imperative.

Identification and counting of prey hard parts could indicate the number of a given prey species consumed during a feeding bout or during several feedings (Jobling and Breiby 1986). Many marine mammals probably alternate between feeding and periods of rest. In this study, the varied state of digestion of the stomach contents and the sometimes large numbers of prey items found in an individual stomach would indicate an 
accumulation of prey hard parts from several meals. Common dolphins probably need to feed several times per day to obtain their needed ration of food (Overholz and Waring 1991). Schmidt (1923) found at least 15,191 otoliths in the stomach of a common dolphin, probably short-beaked, that had been harpooned off southern Spain in the Mediterranean. Frost (1924) examined 4,338 of these otoliths and assigned them to six species belonging to three families: Myctophidae (4,324), Scomberesocidae (4), and possibly Macrouridae (10). Fitch and Brownell (1968) examined stomach contents of two common dolphins off southern California. One dolphin had eaten a minimum of 63 fish belonging to six species, dominated by Pacific hake and northern anchovy. The other dolphin had eaten at least 72 fish belonging to four species, dominated by northern anchovy. Jones (1981) examined the stomach contents of a common dolphin that stranded off north-central California. It contained 11 otoliths representing two species, medusafish and an osmerid, and four Loligo beaks. Energy budget calculations by Overholz and Waring (1991) based on four common dolphin stomachs indicated that the amount of observed prey (three to six Atlantic mackerel, total weight of 339 to $2,420 \mathrm{~g}$ ) would supply six to 44 percent of the daily theoretical requirement.

Cumulative species curves indicated that at least 25 stomachs of common dolphins in the by-catch and at least 17 stomachs of common dolphins that had stranded were needed to assess food habits of common dolphins; however, only 14 stomachs of long-beaked common dolphin in the by-catch were collected. Precision of estimates of mean numbers of prey species eaten improved as sample sizes increased as indicated by narrowing standard errors. In 1992, Southwest Fisheries Science Center estimated 
common dolphin (species were not differentiated) mortality in the set gillnet fishery to be 17 animals, and in the drift gillnet fishery to be 356 animals (Schmitten 1994).

Short-beaked common dolphin tend to spend more time offshore than long-beaked common dolphin. It would be expected that a greater number of short-beaked common dolphin would be impacted by fisheries than long-beaked common dolphin, which may explain why fewer stomach samples were available of long-beaked common dolphin in the by-catch.

In this study, common dolphins in the by-catch had greater species richness, diversity, niche breadth, and evenness than common dolphins that had stranded; however, the opposite was true for specialization and dominance. It would appear that common dolphins in the by-catch utilized a wider variety of food resources and habitats than common dolphins that had stranded. It has been stated that food items in stomachs of stranded animals may not accurately reflect the feeding habits of healthy animals capable of normal foraging behavior (Hall 1977, Leatherwood and others 1978, Selzer and others 1986, Pierce and Boyle 1991). Dolphins in debilitated condition may not be feeding in regular feeding sites or may not be able to secure normal prey. Walker (1975) found that common dolphins captured for display appeared to be essentially free of debilitating parasites, such as trematodes in the air sinuses, pancreas, liver, and brain, commonly seen in stranded Delphinus in the southern California area (Cowan and others 1986, Ridgway and Dailey 1972). Cowan and others (1986) examined 81 stranded small cetaceans and found that all animals in the study were sick with parasites or other disease, had obvious damage to the middle ear apparatus, or were injured. 
It has been stated that the presence of food in the stomach of stranded individuals generally indicates some form of sudden, untimely death, as chronically ill marine mammals which strand often have empty stomachs (DeMaster and others 1985, Seagars and Henderson 1985, Selzer and others 1986, Gales and Pemberton 1992, Heyning and others 1994). Generally, in the current study, dolphins that had stranded had fewer prey items in their stomachs than dolphins in the by-catch. Dolphins with empty stomachs were not considered in this study. It appears that the final stage of death in many debilitated dolphins is fairly rapid and they probably have eaten within a few days of stranding. After two weeks in captivity, a Pacific white-sided dolphin began showing signs of incoordination and subsequently died within 24 hours (Ridgway and Daily 1972). This dolphin had numerous brain lesions with massive numbers of parasite ova in the brain. Cowan and others (1986) found that most stranded small cetaceans were of normal body weight despite having very large or multiple brain lesions. These results implied that the complex neuromuscular functions involved in identifying, tracking, and capturing prey continued to function until near death. Captive dolphins lose weight very quickly during short periods of inappetance, when debilitated by disease, or when subjected to environmental stress (Walker 1975). Newly captured common dolphins that refuse to eat can die from starvation within three to 10 days (Brown and Norris 1956, Walker 1975).

In this study, short-beaked common dolphin in the by-catch ate different predominant prey than short-beaked common dolphin that had stranded. Common dolphins in the by-catch would presumably have been feeding further offshore when they were caught compared to dolphins that had been feeding nearshore before stranding. 
Whole or relatively undigested prey indicate consumption near the location of death, alternatively, beaks alone may represent accumulations of previous feedings, and the animal could have traveled a considerable distance from where the prey was consumed (Fiscus 1982, Clarke 1986b). Stranded cetaceans might be expected to have stomach contents biased towards inshore prey species (Clarke 1986b). Prey species of short-beaked common dolphin that had stranded were a mixture of oceanic and neretic species. Gales and Pemberton (1992) also found that long-finned pilot whales (Globicephala melaena) had fed on their way into shallower water before stranding. Long-beaked common dolphin in the by-catch and those that had stranded had similar food habits. Because long-beaked common dolphin tend to be found nearshore, animals in the by-catch and those that had stranded should have similar prey available to them. Similarly, Leatherwood and others (1978) did not observe any differences in stomach contents of six stranded and three entangled bottlenose dolphins (Tursiops truncatus) from the northeastern United States coast. Barros and Odell (1990) compared prey composition of nine presumably healthy (probable fishery-related) and eleven sick (stranded) coastal bottlenose dolphins off the southeastern United States and found that the same important prey species occurred in both groups.

Although diet of short-beaked common dolphin in the by-catch and long-beaked common dolphin in the by-catch appeared statistically similar, they did not appear to have similar diets graphically. Short-beaked common dolphin are found both offshore and nearshore, however, overall they may spend more time offshore or tend to feed more offshore than nearshore. If long-beaked common dolphin tend to feed more nearshore 
then overlap would occur with short-beaked common dolphin in the nearshore habitat. Coastal and offshore bottlenose dolphins have different diets (Walker 1981, Van Waerebeek and others 1990). Coastal bottlenose dolphins off southern California ate primarily littoral and sublittoral fishes and invertebrates, whereas, offshore dolphins ate epipelagic fish and cephalopods (Walker 198i ). Off Peru, there was overlap of some prey species, such as, Pacific sardine, anchoveta (Engraulis ringens), and hake (Merluccius gayi); however, there were distinct differences, including inshore demersal fishes eaten by coastal dolphins and mesopelagic fishes and squids eaten by offshore dolphins (Van Waerebeek and others 1990). Barros and Odell (1990) examined a specimen of the offshore variety of bottlenose dolphin off Florida and found different prey species than those taken by coastal dolphins; however, due to the small sample size these results were inconclusive.

Short-beaked common dolphin that had stranded and long-beaked common dolphin that had stranded had similar predominant prey. It would seem that dolphins that are in the process of stranding would have similar nearshore prey species available to them.

Male and female common dolphins probably fed together. Male and female common dolphins have been captured for display out of the same school (Walker 1975), which is evidence that they probably do not segregate by sex.

The seasonal migratory pattern of prey species should be considered because some prey species may be more available to common dolphins at certain times of the year. In the present study, predominant prey species did not significantly change among the three 
oceanographic periods, however, sample sizes among periods were unequal. Larger and more even sample sizes for each period are needed to reach a more definitive conclusion.

The nocturnal movement of certain prey species toward the surface at night makes them more accessible to marine mammals. Some prey species may be accessible to common dolphins only at night because their daytime distribution is deeper than the reported diving capabilities of common dolphins. The maximum depth of dive recorded for a common dolphin is slightly more than $\mathbf{2 0 0} \mathrm{m}$; however, most dives are in the range of nine to $50 \mathrm{~m}$ (Evans 1994). Most myctophid and bathylagid fish species, and gonatid squid species, are found below $400 \mathrm{~m}$ during the day but migrate within the diving depth of common dolphins at night (Paxton 1967, Cailliet and Ebeling 1990). Evans (1975) conducted midwater trawls in conjunction with tracking a tagged Delphimus. The catch of two trawls in the vicinity of the diving dolphin consisted of $90 \%$ bathylagid and myctophid fishes. All fish species collected had been observed in stomach contents of Delphimus. The dolphin's diving pattern changed in relation to the migration pattern of the deep scattering layer. As the scattering layer migrated to the surface the dolphin changed from shallow dives to regular dives to $50 \mathrm{~m}$ depth until the layer descended at first light and the dolphin ceased diving.

Common dolphins fed on a variety of fishes and cephalopods and, based on habits of prey species found in this study, probably fed both nocturnally and diurnally. Although some of the same prey species were eaten by both species of common dolphin, there were clear differences in their diets. Predominant prey of short-beaked common dolphin in the by-catch generally approach the surface only at night, with the exception of Pacific 
mackerel (Scomber japonicus), which can be found near the surface during the day. Based on prey habits, it would appear that short-beaked common dolphin may be more of a specialist and probably fed primarily at night. Predominant prey of long-beaked common dolphin in the by-catch included two species that generally approach the surface only at night and five species that inhabit near surface waters. Based on prey habits, it would appear that long-beaked common dolphin fed opportunistically, both diurnally and nocturnally. Common dolphins that had stranded fed on three prey species that approach the surface only at night and five species that inhabit near surface waters. This would indicate that dolphins that had stranded fed opportunistically, both diurnally and nocturnally, before stranding.

Common dolphins may restrict their diet to certain species based on size. In the present study, common dolphins generally fed on prey less than $20 \mathrm{~cm}$ long, which included mostly juveniles of larger fishes and cephalopods and juveniles to adults of smaller fishes and cephalopods. Evans (1975) examined stomach contents of 36 common dolphins and described them as being catholic feeders, and reported that they preyed on those species of a suitable size (usually less than $15 \mathrm{~cm}$ ) which are the most abundant or catchable. Overholtz and Waring (1991) reported common dolphins selected mackerel from certain age classes (5-8 years), however, this pattern may have reflected the absence of smaller, younger fish offshore and low abundance of older, larger fish.

Seasonal variation in sea surface temperature and salinity, and local nutrient upwelling in areas of high sea floor relief may affect preferred prey abundances, which in turn may affect dolphin distribution. Dohl and others (1986) found two distinct seasonal 
distributions for common dolphins in the Southern California Bight (SCB), with widespread sightings from July through December and sightings concentrated in the eastern SCB from January through June. These movements appeared to be temperature related. Evans (1975) found that common dolphins moved northward from southern California during July to November and southward from December to June. Before 1991, Pacific white-sided dolphin (Lagenorhynchus obliquidens) was the most numerous cetacean sighted in Monterey Bay (Black 1994), probably because it is more often found associated with cooler water temperatures. Since 1991, however, common dolphin have been more abundant than Pacific white-sided dolphin seasonally, indicating local temperatures may be warmer recently. Occasional sightings of short beaked common dolphin in summer, when water temperatures are cooler, would indicate that short-beaked common dolphin is more tolerant of colder temperatures than long-beaked common dolphin (personal observation, Heyning and Perrin 1994).

Increased sightings of common dolphins off central California in recent years may indicate a change in distributional patterns reflective of prey distribution relating to water temperature. Since the early 1990 's, there have been regular sightings of common dolphins off central California, generally from fall through spring, with occasional sightings of short-beaked common dolphin in summer (personal observation). This northward advance may be attributed to the warming of surface waters caused by El Nino. Others have noted that distribution of common dolphins has been correlated with water temperatures and bottom topography, factors which concentrate prey (Evans 1975, Hui 1985, Dohl and others 1986, Leatherwood and Reeves 1986, Selzer and Payne 1988). 
Common dolphin distribution also may be influenced by the physiological response of dolphins to water temperature and distribution may change in response to maintaining an optimal thermoneutral zone thus reducing the need to increase food intake. Ross and Cockcroft (1990) examined the effect of changes in water temperature on energy intake, in terms of feeding rate, using a captive bottlenose dolphin. They determined the thermoneutral zone for this dolphin, and found that with increasing water temperature there was a decrease in feeding rate. They also found that wild bottlenose dolphins lived in conditions near or below the lower limit of their thermoneutral zone for most of the year. 


\section{LITERATURE CITED}

Bailey, K.M., Francis, R.C., Stevens, P.R. 1982. The life history and fishery of Pacific whiting, Merluccius productus. CalCOFI Rept. 23:81-98.

Barros, N.B., Odell, D.K. 1990. Food habits of bottlenose dolphins in the southeastern United States. In: The bottlenose dolphin. Leatherwood, S., Reeves, R.R. (eds.). San Diego: Academic Press, Inc. pp. 309-328.

Baxter, J.L. 1966. Summary of biological information on the northern anchovy Engraulis mordax Girard. CalCOFI Rept. 11:110-116.

Bigg, M.A., Fawcett, I. 1985. Two biases in diet determination of northern fur seals (Callorhinus ursimus). In: Marine mammals and fisheries. Beddington, J.R., Beverton, R.J.H., Lavigne, D.M. (eds.). London: George Allen and Unwin, Ltd. pp. 284-291.

Black, N.A. 1994. Behavior and ecology of Pacific white-sided dolphins (Lagenorhynchus obliquidens) in Monterey Bay, California. M.S. Thesis. San Francisco State University. $133 \mathrm{pp}$.

Brown, D.H., Norris, K.S. 1956. Observations of captive and wild cetaceans. J. Mamm. 37(3):311-326.

Butler, T.H. 1980. Shrimps of the Pacific coast of Canada. Can. Bull. Fish. Aquat. Sci. 202:1-280.

Cailliet, G.M., Ebeling, A.W. 1990. The vertical distribution and feeding habits of two common midwater fishes (Leuroglossus stilbius and Stenobrachius leucopsarus) off Santa Barbara. CalCOFI Report 31:106-123.

Clarke, M.R. 1986a. A handbook for the identification of cephalopod beaks. Oxford: Clarendon Press. 273 pp.

Clarke, M.R. 1986b. Cephalopods in the diet of odontocetes. In: Research on dolphins. Bryden, M.M., Harrison, R. (eds.). Oxford: Clarendon Press. pp. 281-321.

Co:van, D.F., Walker, W.A., Brownell, R.L., Jr. 1986. Pathology of small cetaceans stranded along southern California beaches. In: Research on dolphins. Bryden, M.M., Harrison, R. (eds.). Oxford: Clarendon Press. pp. 323-367. 
da Silva, J., Neilson, J.D. 1985. Limitations of using otoliths recovered in scats to estimate prey consumption in seals. Can. J. Fish. Aquat. Sci. 42(8):1439-1442.

Day, R.W., Quinn, G.P. 1989. Comparisons of treatments after an analysis of variance in ecology. Ecol. Monogr. 59(4):433-463.

DeMaster, D., Miller, D., Henderson, J.R., Coe, J.M. 1985. Conflicts between marine mammals and fisheries off the coast of California. In: Marine mammals and fisheries. Beddington, J.R., Beverton, R.J.H., Lavigne, D.M. (eds.). London: George Allen and Unwin, Ltd. pp. 111-118.

Diamond, S.L., Scholl, J.P., Hanan, D.A. 1987. Drift gill net observations for the 198586 fishing season. Nat. Mar. Fish. Serv. Admin. Rep. SWR 87-4. 21 pp.

Dohl, T.P., Bonnell, M.L., Ford, R.G. 1986. Distribution and abundance of common dolphin, Delphinus delphis, in the southern California bight: a quantitative assessment based upon aerial transect data. Fishery Bull. 84(2):333-343.

Duffy, J. M. 1992. Octopuses. In: California's living marine resources and their utilization. Leet, W.S., Dewees, C.M., Haugen, C.W. (eds.). Sea Grant Extension Publ. UCSGEP-92-12, Univ. of Calif., Davis. pp. 194-195.

Ellerman, J.R., Morrison-Scott, T.C.S. 1951. Checklist of Palaearctic and Indian mammals 1758 to 1946 . London: Br. Mus. Nat. History. $810 \mathrm{pp}$.

Evans, W.E. 1975. Distribution, differentiation of populations, and other aspects of the natural history of Delphimus delphis Linnaeus in the northeastern Pacific. Ph.D. diss., Univ. of Calif., Los Angeles. 164 pp.

Evans, W.E. 1982. Distribution and differentiation of stock of Delphinus delphis Linnaeus in the northeastern Pacific. In: Mammals in the seas, volume 4. Rome: Food and Agric. Organ. of the United Nations. pp. 45-66.

Evans, W.E. 1994. Common dolphin, white-bellied porpoise Delphinus delphis Linnaeus, 1758. In: Handbook of marine mammals, volume 5: The first book of dolphins. Ridgway, S.H., Harrison, R. (eds.). London: Academic Press. pp. 191-224.

Field, J.G. 1970. The use of numerical methods to determine benthic distribution patterns from dredgings in False Bay. Trans. R. Soc. South Africa 39:183-200.

Fields, W.G. 1965. The structure, development, food relations, reproduction, and life history of the squid Loligo opalescens Berry. Fish Bull. 131. 107 pp. 
Fiscus, C.H. 1979. Interactions of marine mammals and Pacific hake. Mar. Fish. Rev. 41(10):1-9.

Fiscus, C.H. 1982. Predation by marine mammals on squids of the eastern north Pacific ocean and the Bering sea. Mar. Fish. Rev. 44(2):1-10.

Fiscus, C.H., Baines, G.A. 1966. Food and feeding behavior of steller and California sea lions. J. Mamm. 47(2): 195-200.

Fiscus, C.H., Niggol, K. 1965. Observations of cetaceans off California, Oregon and Washington. U.S. Fish Wildl. Serv. Spec. Sci. Rep. Fish. 498. 27 pp.

Fitch, J.E. 1967. The marine fish fauna, based primarily on otoliths, of a lower pleistocene deposit at San Pedro, California (LACMIP 332, San Pedro sand). Los Angeles County Mus. Contrib. Sci. 128. 23 pp.

Fitch, J.E. 1968. Otoliths and other fish remains from the Timms Point silt (early pleistocene) at San Pedro, California. Los Angeles County Mus. Contrib. Sci. 146. $29 \mathrm{pp}$.

Fitch, J.E. 1969. Fossil lanternfish otoliths of California, with notes on fossil myctophidae of North America. Los Angeles County Mus. Contrib. Sci. 173. $20 \mathrm{pp}$.

Fitch, J.E., Brownell, R.L., Jr. 1968. Fish otoliths in cetacean stomachs and their importance in interpreting feeding habits. J. Fish. Res. Board Can. 25(12):25612574.

Fitch, J.E., Lavenberg, R.J. 1968. Deep-water teleostean fishes of California. Berkeley: University of California Press. 155 pp.

Frost, G.A. 1924. Fish otoliths from the stomach of a porpoise. Nature 113(2835):310.

Gales, R., Pemberton, D. 1992. Stomach contents of long-finned pilot whales (Globicephala melas) and bottlenose dolphins (Tursiops truncatus) in Tasmania. Mar. Mamm. Sci. 8(4):405-413.

Govoni, J.J., Hoss, D.E., Chester, A.J. 1983. Comparative feeding of three species of larval fishes in the northern Gulf of Mexico: Brevoortia patromus, Leiostomus xanthurus, and Micropogonias undulatus. Mar. Ecol. Prog. Ser. 13: 189-199.

Hall, J.D. 1977. A nonlethal lavage device for sampling stomach contents of small marine mammals. Fishery Bull. 75(3):653-656. 
Hall, E.R. 1981. The mammals of North America, Vol. II, 2nd ed. New York: John Wiley and Sons, v-vi +601-1181, 1-90 pp.

Harkonen, T. 1986. Guide to the otoliths of the bony fishes of the northeast Atlantic. Hellurup, Denmark: Danbiu ApS. Biological Consultants. 256 pp.

Hart, J.L. 1973. Pacific fishes of Canada. Fish. Res. Board Can. Bull. 180. 740 pp.

Harvey, J.T. 1987. Population dynamics, annual food consumption, movements and dive behaviors of harbor seals, Phoca vitulina richardsi, in Oregon. Ph.D. diss., Oregon State University. $177 \mathrm{pp}$.

Harvey, J.T., Antonelis, G.A. 1994. Biases associated with non-lethal methods of determining the diet of northern elephant seals. Mar. Mamm. Sci. 10(2):178-187.

Harvey, J.T., Loughlin, T.R., Perez, M.A., Oxman, D.S. In press. Relationship between fish size and otolith length for 62 species of fishes from the eastern north Pacific ocean. NOAA Tech. Rept. NMFS Circular.

Hershkovitz, P. 1966. Catalog of living whales. U. S. Nat. Mus. Bull. 246. 259 pp.

Heyning, J.E., Perrin, W.F. 1991. Re-examination of two forms of common dolphins (genus Delphinus) from the eastern North Pacific; Evidence for two species. Southwest Fish. Sci. Center Admin. Rept. LJ-91-28. 37 pp. + 16 figures.

Heyning, J.E., Perrin, W.F. 1994. Evidence for two species of common dolphins (genus Delphinus) from the eastern north Pacific. Nat. Hist. Mus. Los Angeles County Contrib. Sci. 442:1-35.

Heyning, J.E., Lewis, T.D., Woodhouse, C.D. 1994. A note on odontocete mortality from fishing gear entanglements off southern California. Rep. Int. Whal. Comm. Special Issue 15. pp. 439-442.

Hixon, R.F. 1983. Loligo opalescens. In: Cephalopod life cycles, Vol.1. Boyle, R.P. (Ed.). London: Academic Press. pp. 95-114.

Honacki, J.H., Kinman, K.E., Koeppl, J.W. (eds.) 1982. Mammalian species of the world. Lawrence, Kansas: Allen Press, Inc. and The Association of Systematics Collections. 694 pp.

Hui, C.A. 1985. Undersea topography and the comparative distributions of two pelagic cetaceans. Fishery Bull. 83(3):472-475. 
Hyslop, E.J. 1980. Stomach contents analysis - a review of methods and their application. J. Fish Biol. 17:411-429.

Iverson, I.L.K., Pinkas, L. 1971. A pictorial guide to beaks of certain eastern Pacific cephalopods. Fish Bull. 152:83-105.

Jacobson, L.D. 1992. Northern anchovy. In: California's living marine resources and their utilization. Leet, W.S., Dewees, C.M., Haugen, C.W. (eds.). Sea Grant Extension Publication UCSGEP-92-12, Univ. of Calif., Davis. pp. 81-82.

Jefferts, K. 1982. Zoogeography and systematics of cephalopods of the northeastern Pacific ocean. Ph.D. diss., Oregon State University. 291 pp.

Jobling, M. 1987. Marine mammal faeces samples as indicators of prey importance - a source of error in bioenergetics studies. Sarsia 72 (3-4):255-260.

Jobling, M., Breiby, A. 1986. The use and abuse of fish otoliths in studies of feeding habits of marine piscivores. Sarsia 71:265-274.

Jones, R.E. 1981. Food habits of smaller marine mammals from northern California. Proc. Calif. Acad. Sci. 42(16):409-433.

Krebs, C.J. 1989. Ecological methodology. New York: Harper Collins Publishers. $654 \mathrm{pp}$.

Laroche, J.L. 1982. Trophic patterns among larvae of five species of sculpins (family: Cottidae) in a Maine estuary. Fishery Bull. 80(4): 827-840.

Leatherwood, S., Reeves, R.R. 1986. Porpoises and dolphins. In: Marine mammals of eastern north Pacific and Arctic waters, Second Edition. Haley, D. (Ed.). Seattle: Pacific Search Press. pp. 110-131.

Leatherwood, S., Deerman, M.W., Potter, C.W. 1978. Food and reproductive status of nine Tursiops truncatus from the northeastern United States coast. Cetology 28:1-6.

Mais, K.F. 1974. Pelagic fish surveys in the California current. Fish Bull. 162:1-79.

Miller, D.J., Lea, R.N. 1972. Guide to the coastal marine fishes of California. Fish Bull. 157. 249 pp. 
Mitchell, E. (Ed.). 1975. Report of the meeting on smaller cetaceans, Montreal, April 111, 1974. J. Fish. Res. Board Can. 32:889-983.

Murie, D.J., Lavigne, D.M. 1985. Digestion and retention of Atlantic herring otoliths in the stomachs of grey seals. In: Marine mammals and fisheries. Beddington, J.R., Beverton, R.J.H., Lavigne, D.M. (eds.). London: George Allen and Unwin, Ltd. pp. 292-299.

Nelson, M.O., Larkins, H.A. 1970. Distribution and biology of Pacific hake: A synopsis. In: Pacific hake. U.S. Fish Wildl. Circ. 332. pp. 23-33.

Nesis, K.N. 1987. Cephalopods of the world. Neptune City, NJ: T.F.H. Publications, Inc. $351 \mathrm{pp}$.

Norris, K.S., Prescott, J.H. 1961. Observations on Pacific cetaceans of Californian and Mexican waters. Univ. Calif. Pub. Zool. 63(4):309-311

Overholtz, W.J., Waring, G.T. 1991. Diet composition of pilot whales Globicephala sp. and common dolphins Delphinus delphis in the mid-Atlantic bight during spring 1989. Fishery Bull. 89(4):723-728.

Paxton, J.R. 1967. A distributional analysis for the lanternfishes (Family Myctophidae) of the San Pedro basin, California. Copeia 2:422-440.

Perrin, W.F., Warner, R.R., Fiscus, C.H., Holts, D.B. 1973. Stomach contents of porpoise, Stenella spp., and yellowfin tuna, Thumus albacares, in mixed-species aggregations. Fishery Bull. 71(4):1077-1092.

Pierce, G.J., Boyle, P.R. 1991. A review of methods for diet analysis in piscivorous marine mammals. Oceanogr. Mar. Biol. Annu. Rev. 29:409-486.

Pitcher, K.W. 1980. Stomach contents and feces as indicators of harbor seal, Phoca vitulina, foods in the Gulf of Alaska. Fishery Bull. 78 (3):797-798.

Ridgway, S.H., Dailey, M.D. 1972. Cerebral and cerebellar involvement of trematode parasites in dolphins and their possible role in stranding. J. Wildl. Diseases 8:33-43.

Roper, C.F.E., Young, R.E. 1975. Vertical distribution of pelagic cephalopods. Smithsonian Contrib. Zool. Number 209. 51 pp. 
Roper, C.F.E., Sweeney, M.J., Nauen, C.E. 1984. FAO species catalogue. Vol. 3. Cephalopods of the world. An annotated and illustrated catalogue of species of interest to fisheries. FAO Fisheries Synopsis 125, Vol. 3. 277 pp.

Rosel, P.E., Dizon, A.E., Heyning, J.E. 1994. Genetic analysis of sympatric morphotypes of common dolphins (genus Delphimus). Mar. Biol. 119:159. 167.

Ross, G.J.B. 1979. The smaller cetaceans of the South East coast of Southern Africa. Ph.D. diss., University of Port Elizabeth. 415 pp.

Ross, G.J.B., Cockcroft, V.G. 1990. Comments on Australian bottlenose dolphins and the taxonomic status of Tursiops aduncus (Ehrenberg, 1832). In: The bottlenose dolphin. Leatherwood, S., Reeves, R.R. (eds.). San Diego: Academic Press, Inc. pp. 101-128.

Schmidt, J. 1923. Consumption of fish by porpoises. Nature 112(2825):902.

Schmitt, W.L. 1921. The marine decapod crustacea of California. Berkeley: University of California Press. 470 pp.

Schmitten, R.A. 1994. Marine Mammal Protection Act of 1972 Annual Report, January 1, 1992 to December 31, 1993. U.S. Dept. of Comm., Nat. Mar. Fish. Serv. 136 pp. + appendices.

Schwartz, M., Hohn, A., Bernard, H., Chivers, S., Peltier, K. 1992. Stomach contents of beach cast cetaceans collected along the San Diego county coast of California, 1972-1991. Southwest Fish. Sci. Ctr. Admin. Rept. LJ-92-18. 33 pp.

Seagars, D.J., Henderson, J.R. 1985. Cephalopod remains from the stomach of a shortfinned pilot whale collected near Santa Catalina Island, California. J. Mamm. 66(4):777-779.

Selzer, L.A., Early, G., Payne, P.M., Prescott, R. 1986. Stranded animals as indicators of prey utilization by harbor seals, Phoca vitulina concolor, in southern New England. Fishery Bull. 84(1):217-220.

Selzer, L.A., Payne, P.M. 1988. The distribution of white-sided (Lagenorhynchus acutus) and common dolphins (Delphinus delphis) vs. environmental features of the continental shelf of the northeastern United States. Mar. Mamm. Sci. 4(2):141-153. 
Stroud, R.K., Fiscus, C.H., Kajimura, H. 1981. Food of the Pacific white-sided dolphin, Lagenorhynchus obliquidens, Dall's porpoise, Phocoenoides dalli, and northern fur seal, Callorhimus ursimus, off California and Washington. Fishery Bull. 78 (4):951-959.

Van Waerebeek, K., Reyes, J.C., Read, A.J., McKinnon, J.S. 1990. Preliminary observations of bottlenose dolphins from the Pacific coast of South America. In: The bottlenose dolphin. Leatherwood, S., Reeves, R.R. (eds.). San Diego: Academic Press, Inc. pp. 143-154.

Walker, W.A. 1975. Review of the live-capture fishery for smaller cetaceans taken in southern California waters for public display, 1966-73. J. Fish. Res. Board Can. 32(7):1197-1211.

Walker, W.A. 1981. Geographical variation in morphology and biology of bottlenose dolphins (Tursiops) in the eastern north Pacific. Southwest Nat. Mar. Fish. Ctr., Contract No. 03-7-208-35238. 52 pp.

Walker, W.A., Jones, L.L. 1993. Food habits of northern right whale dolphin, Pacific white-sided dolphin, and northern fur seal caught in the high seas driftnet fisheries of the north Pacific ocean, 1990. North Pacific Commission Bull. 53 (2):285-295.

Young, R.E. 1972. The systematics and areal distribution of pelagic cephalopods from the seas off southern California. Smithsonian Contrib. Zool. 97. 159 pp.

Zar, J.H. 1984. Biostatistical analysis (second edition). Englewood Cliffs, NJ: Prentice-Hall, Inc. $718 \mathrm{pp}$. 


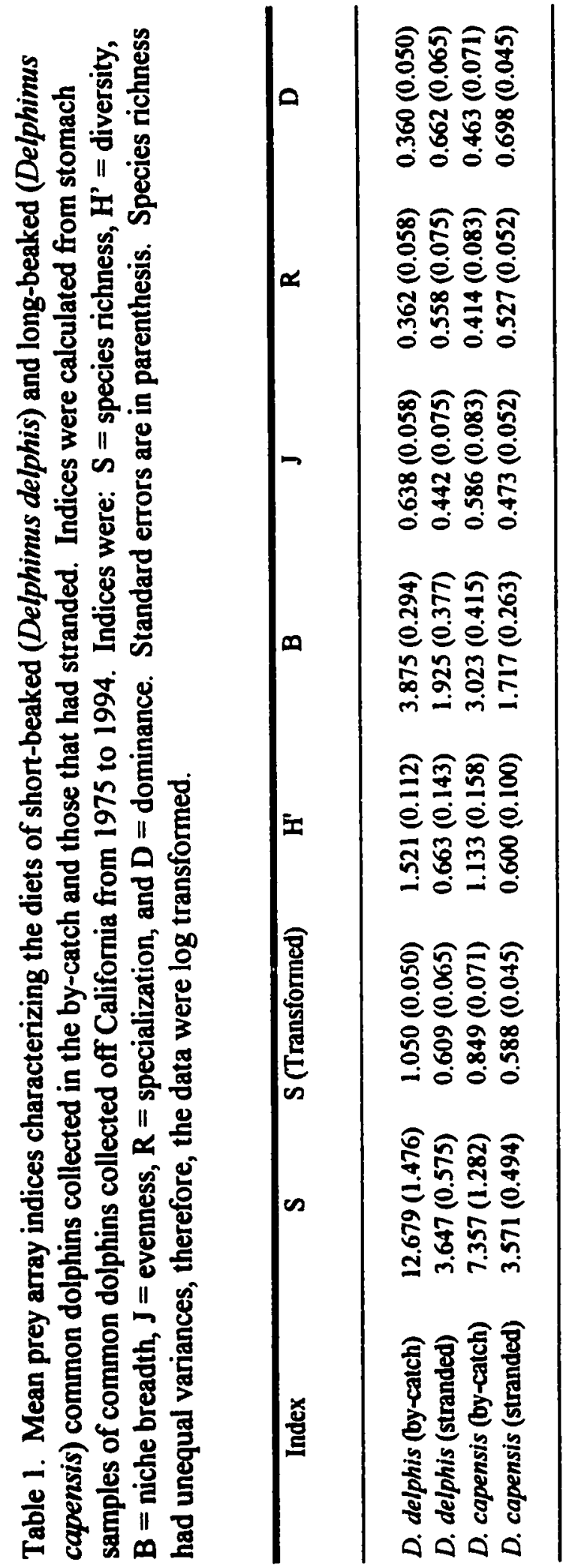


Table 2. Critical values for Ryan's $Q$ test (with Kramer's modification) for the comparison of prey array indices between short-beaked (Delphimus delphis) and long-beaked (Delphimus capensis) common dolphins collected in the by-catch and those that had stranded off California from 1975 to 1994 . Results in bold and underlined indicate a statistically significant difference. Prey array indices values are in parenthesis.

\begin{tabular}{|c|c|c|c|c|}
\hline & $\begin{array}{l}\text { D. delphis } \\
\text { (by-catch) }\end{array}$ & $\begin{array}{l}\text { D. delphis } \\
\text { (stranded) }\end{array}$ & $\begin{array}{l}\text { D. capensis } \\
\text { (by-catch) }\end{array}$ & $\begin{array}{l}\text { D. capensis } \\
\text { (stranded) }\end{array}$ \\
\hline a. Species Richness (S) & $(1.050)$ & $(0.609)$ & $(0.849)$ & $(0.588)$ \\
\hline $\begin{array}{l}\text { Delphinus delphis } \\
\text { (by-catch) }\end{array}$ & & 0.196 & 0.174 & $\underline{0.177}$ \\
\hline $\begin{array}{l}\text { Delphinus delphis } \\
\text { (stranded) }\end{array}$ & & & $\underline{0.191}$ & 0.157 \\
\hline $\begin{array}{l}\text { Delphinus capensis } \\
\text { (by-catch) }\end{array}$ & & & & 0.201 \\
\hline b. Prey Diversity (H') & $(1.521)$ & $(0.663)$ & (1.133) & $(0.600)$ \\
\hline $\begin{array}{l}\text { Delphinus delphis } \\
\text { (by-catch) }\end{array}$ & & 0.434 & $\underline{0.385}$ & $\underline{0.393}$ \\
\hline $\begin{array}{l}\text { Delphinus delphis } \\
\text { (stranded) }\end{array}$ & & & $\underline{0.425}$ & 0.348 \\
\hline $\begin{array}{l}\text { Delphinus capensis } \\
\text { (by-catch) }\end{array}$ & & & & 0.446 \\
\hline c. Niche Breadth (B) & $(3.875)$ & (1.925) & $(3.023)$ & (1.717) \\
\hline $\begin{array}{l}\text { Delphinus delphis } \\
\text { (by-catch) }\end{array}$ & & $\underline{1.141}$ & 1.013 & 1.034 \\
\hline $\begin{array}{l}\text { Delphinus delphis } \\
\text { (stranded) }\end{array}$ & & & 1.116 & 0.915 \\
\hline $\begin{array}{l}\text { Delphinus capensis } \\
\text { (by-catch) }\end{array}$ & & & & 1.174 \\
\hline d. Dominance (D) & $(0.360)$ & $((0.662)$ & $(0.463)$ & $(0.698)$ \\
\hline $\begin{array}{l}\text { Delphinus delphis } \\
\text { (by-catch) }\end{array}$ & & 0.196 & 0.174 & 0.177 \\
\hline $\begin{array}{l}\text { Delphinus delphis } \\
\text { (stranded) }\end{array}$ & & & $\underline{0.191}$ & 0.157 \\
\hline $\begin{array}{l}\text { Delphinus capensis } \\
\text { (by-catch) }\end{array}$ & & & & $\underline{0.201}$ \\
\hline
\end{tabular}




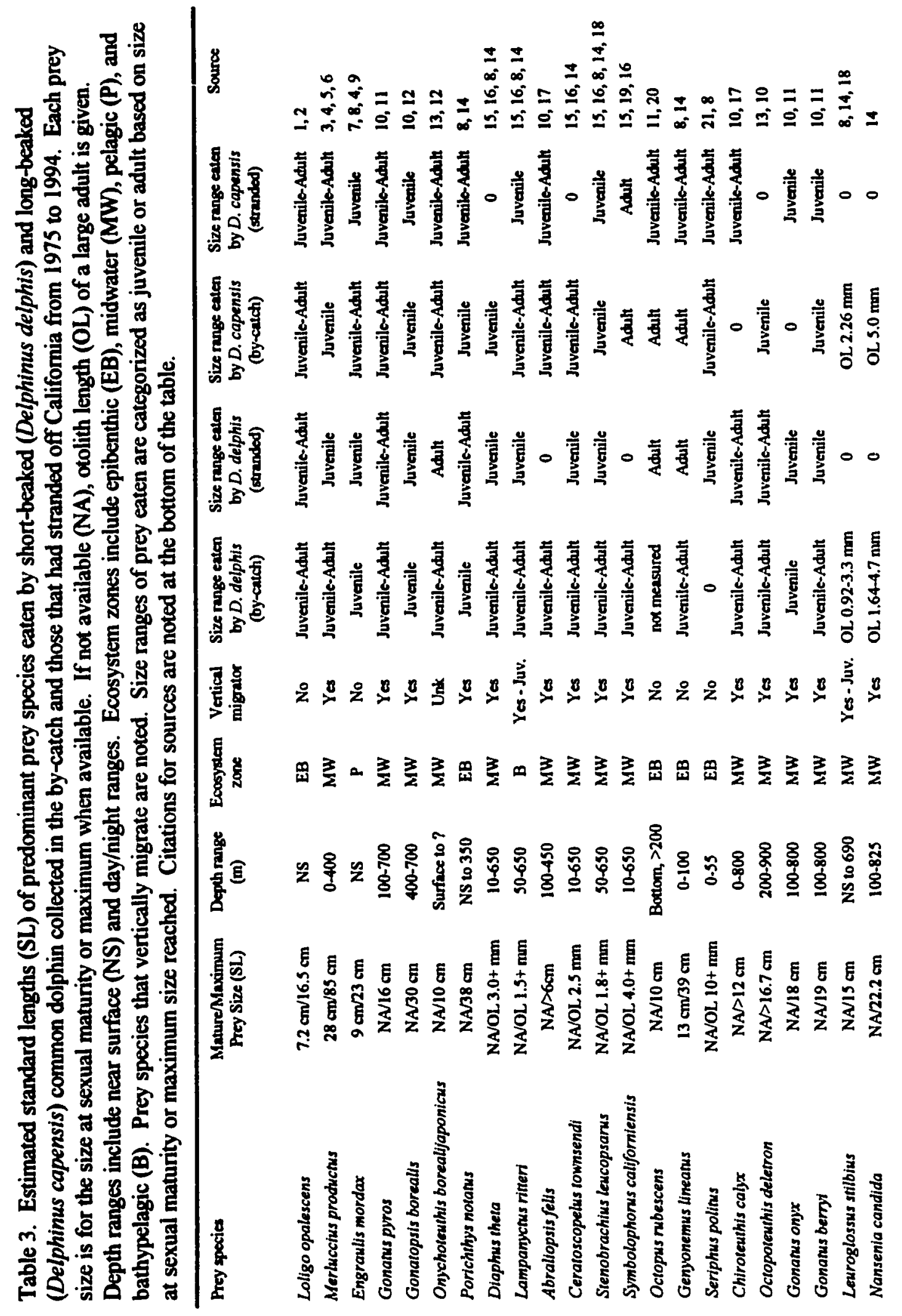




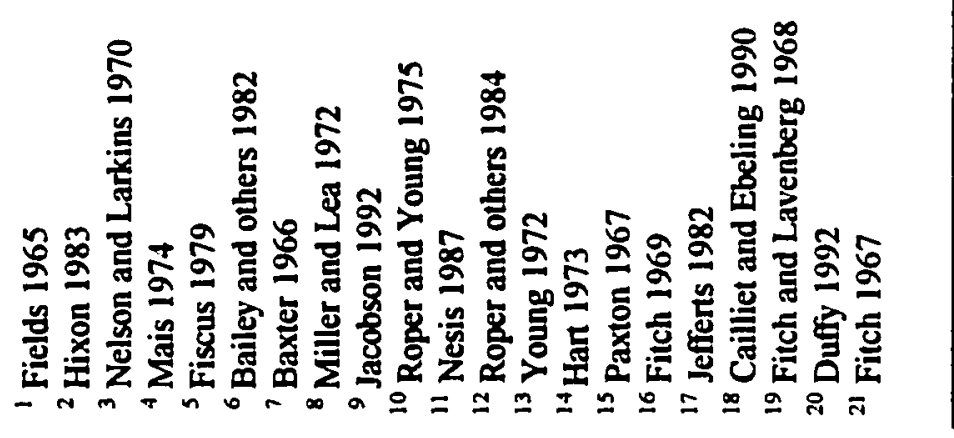




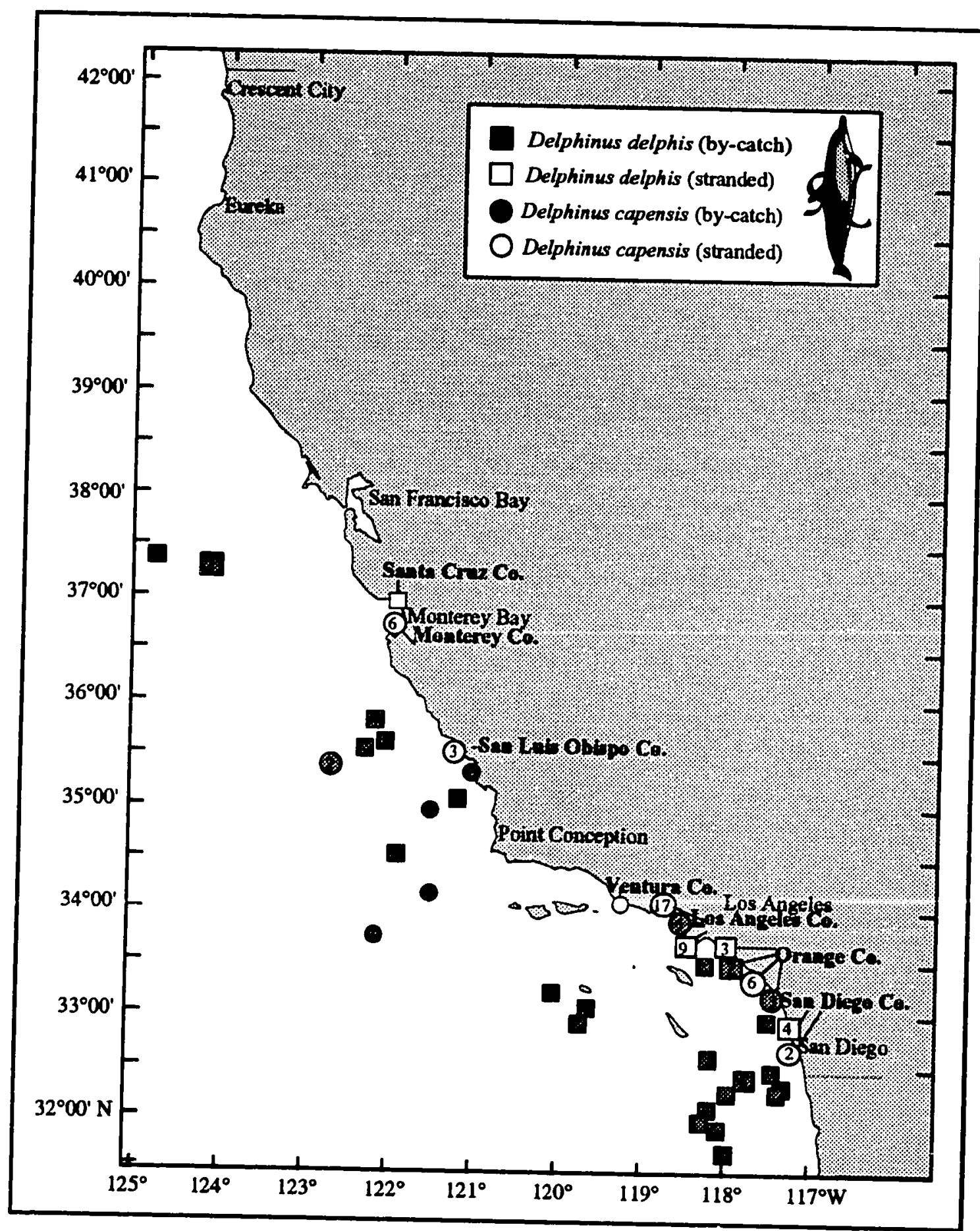

Figure 1. Locations of specimens of short-beaked (Delphinus delphis) and longbeaked (Delphinus capensis) common dolphins collected in the by-catch and those that had stranded off California from 1975 to 1994 . Numbers within circles represent the number of individual specimens found along each county or offshore animals caught in the same gillnet set. 


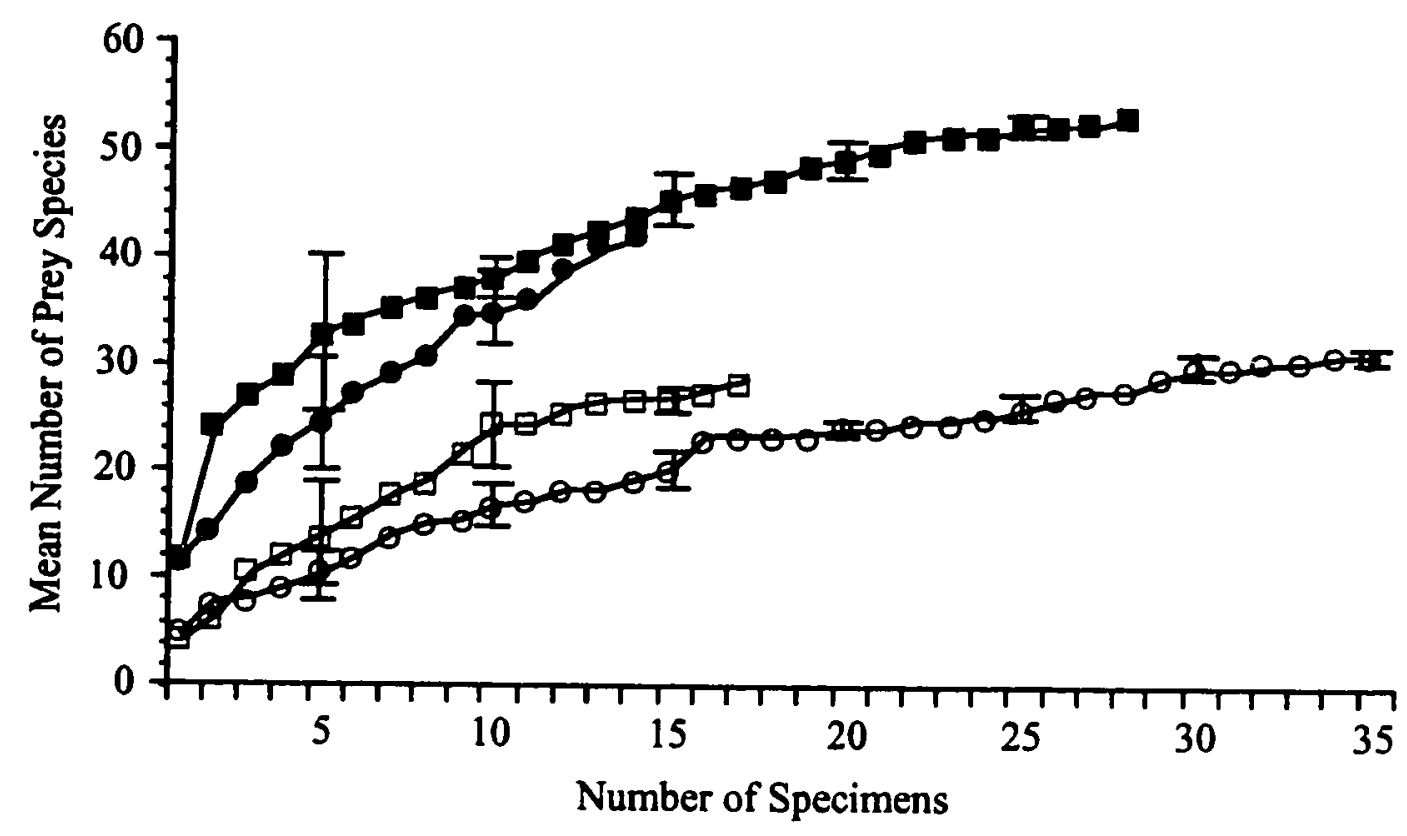

$\rightarrow$ D. delphis (by-catch) $\rightarrow-D$. capensis (by-catch)

$\leftarrow D$. delphis (stranded) $\rightarrow D$. capensis (stranded)

Figure 2. Cumulative prey species curves used to determine minimum number of stomach samples needed to adequately describe food habits of short-beaked (Delphinus delphis) and long-beaked (Delphinus capensis) common dolphins collected in the by-catch and those that had stranded off California from 1975 to 1994. The order in which samples were analyzed was randomized five times and the mean number of new prey species found was plotted against the number of samples. One standard deviation, represented by vertical bars, was plotted for every fifth stomach. 


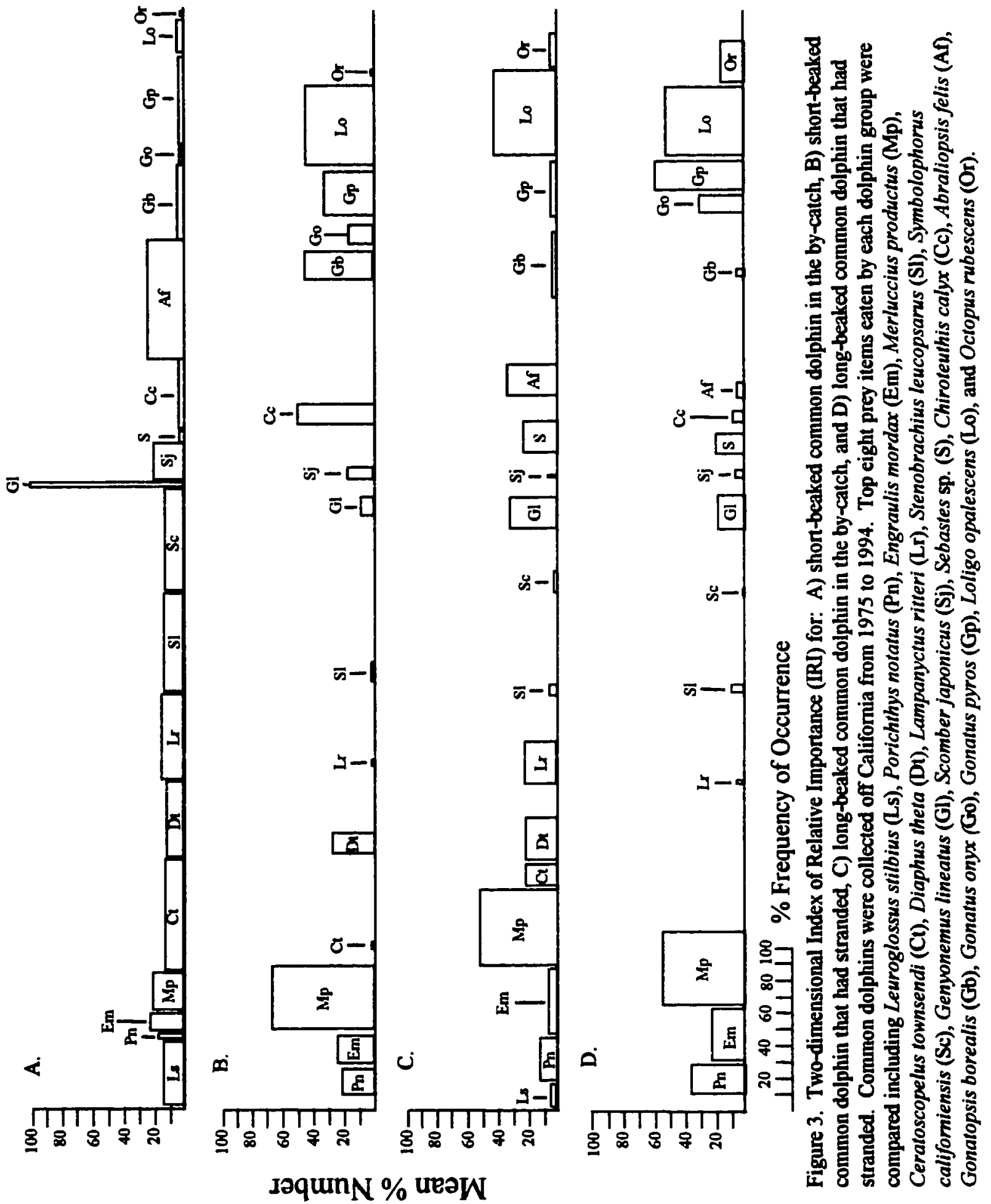




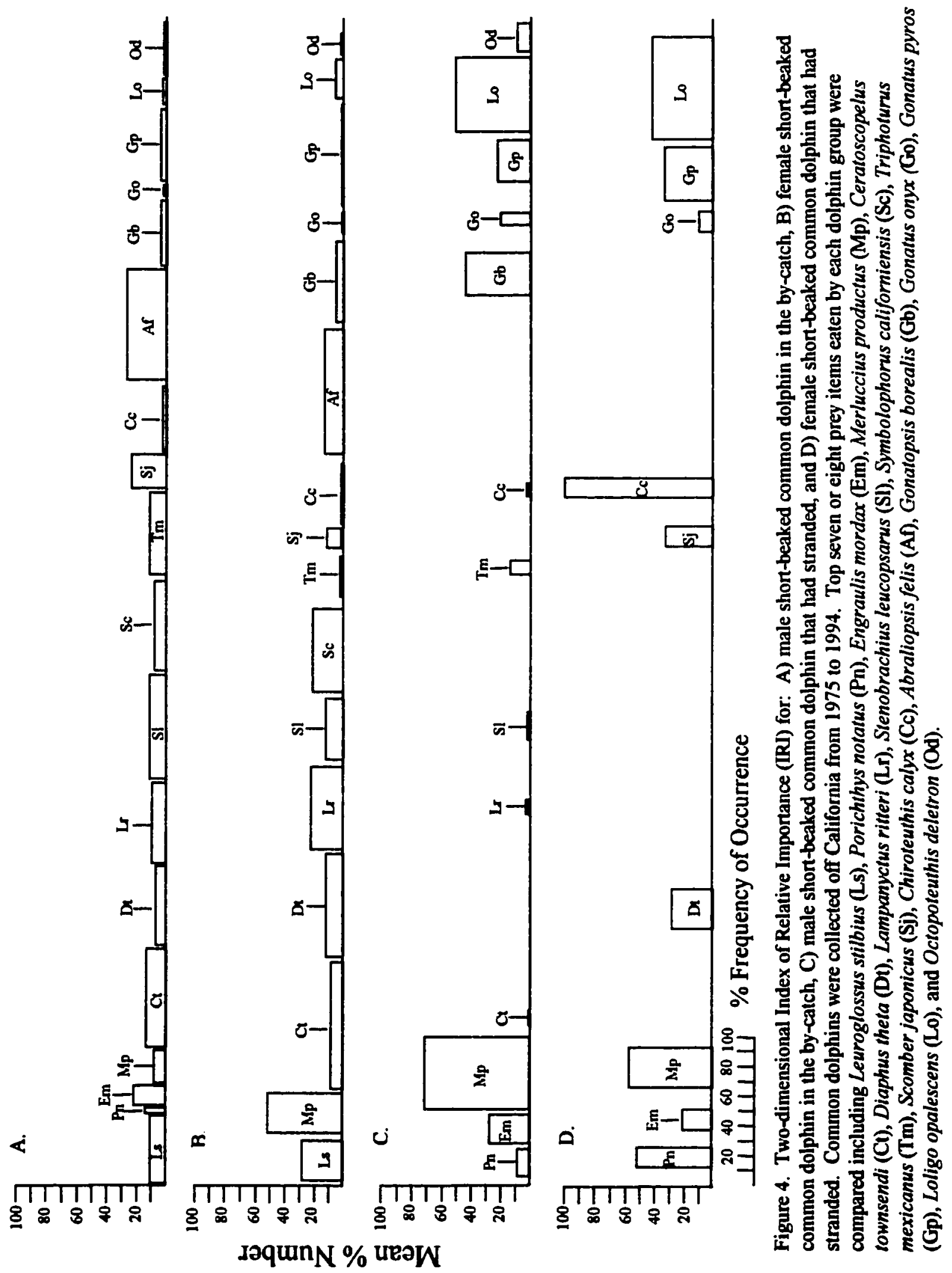




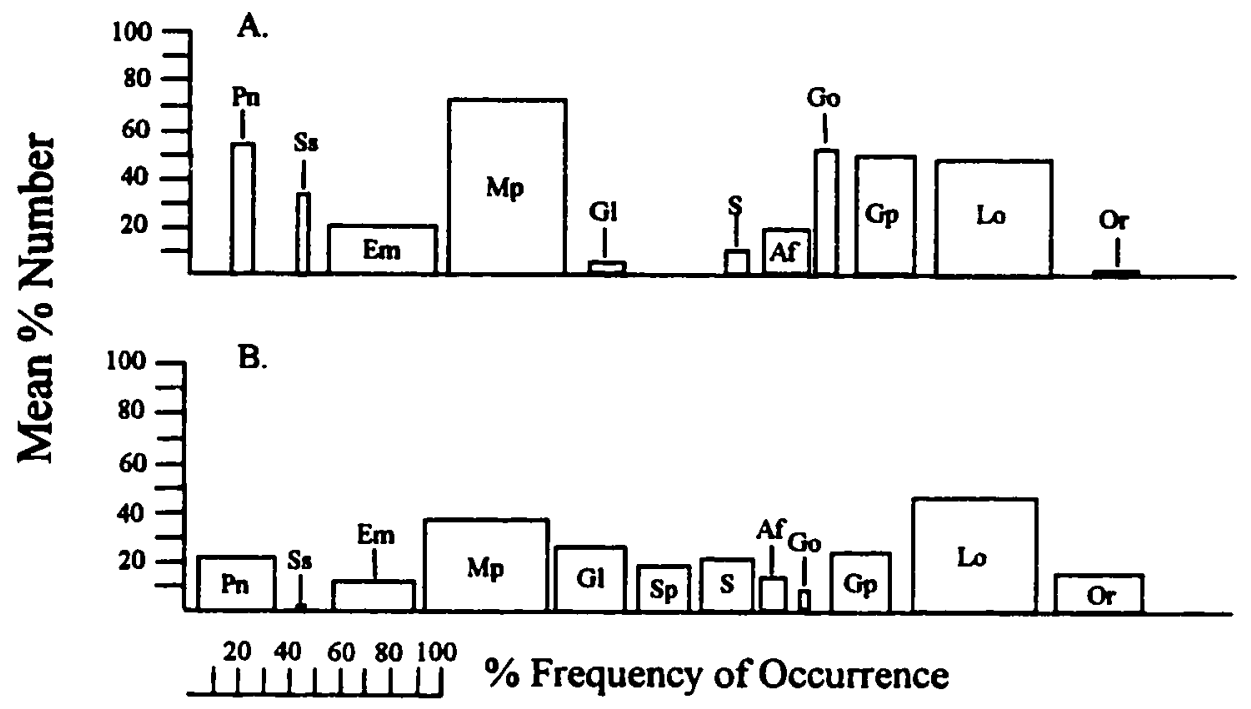

Figure 5. Two-dimensional Index of Relative Importance (IRI) for: A) male long-beaked common dolphin and B) female long-beaked common dolphin. Long-beaked common dolphin in the by-catch and those that had stranded were collected off California from 1978 to 1994 . Top eight prey items eaten by each dolphin group were compared including Porichthys notatus $(\mathrm{Pn})$, Sardinops sagax (Ss), Engraulis mordox (Em), Merluccius productus (Mp), Genyonemus lineatus (Gl), Seriphus politus (Sp), Sebastes sp. (Ss), Abraliopsis felis (Af), Gonatus onyx (Go), Gonatus pyros (Gp), Loligo opalescens (Lo), and Octopus rubescens (Or). 

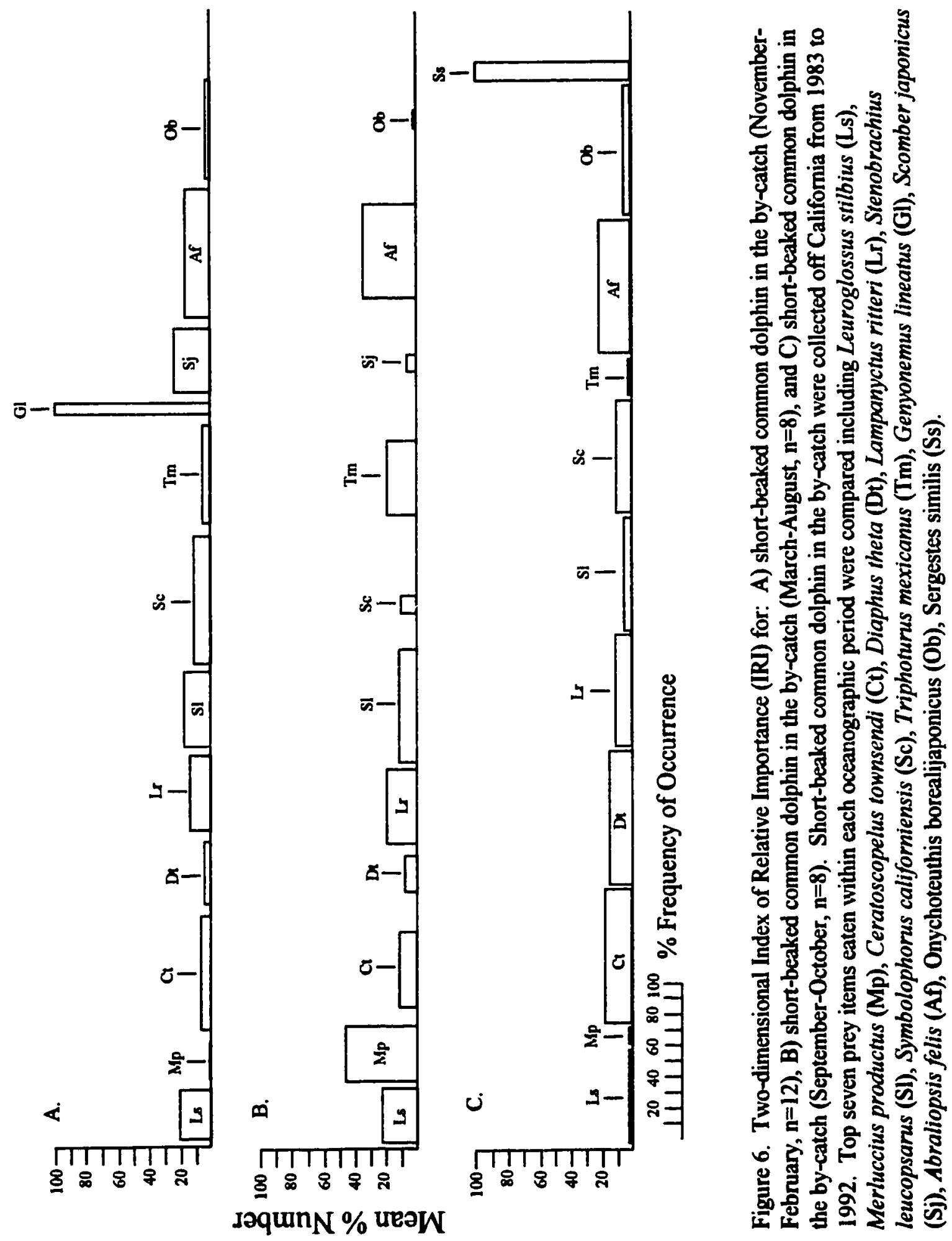


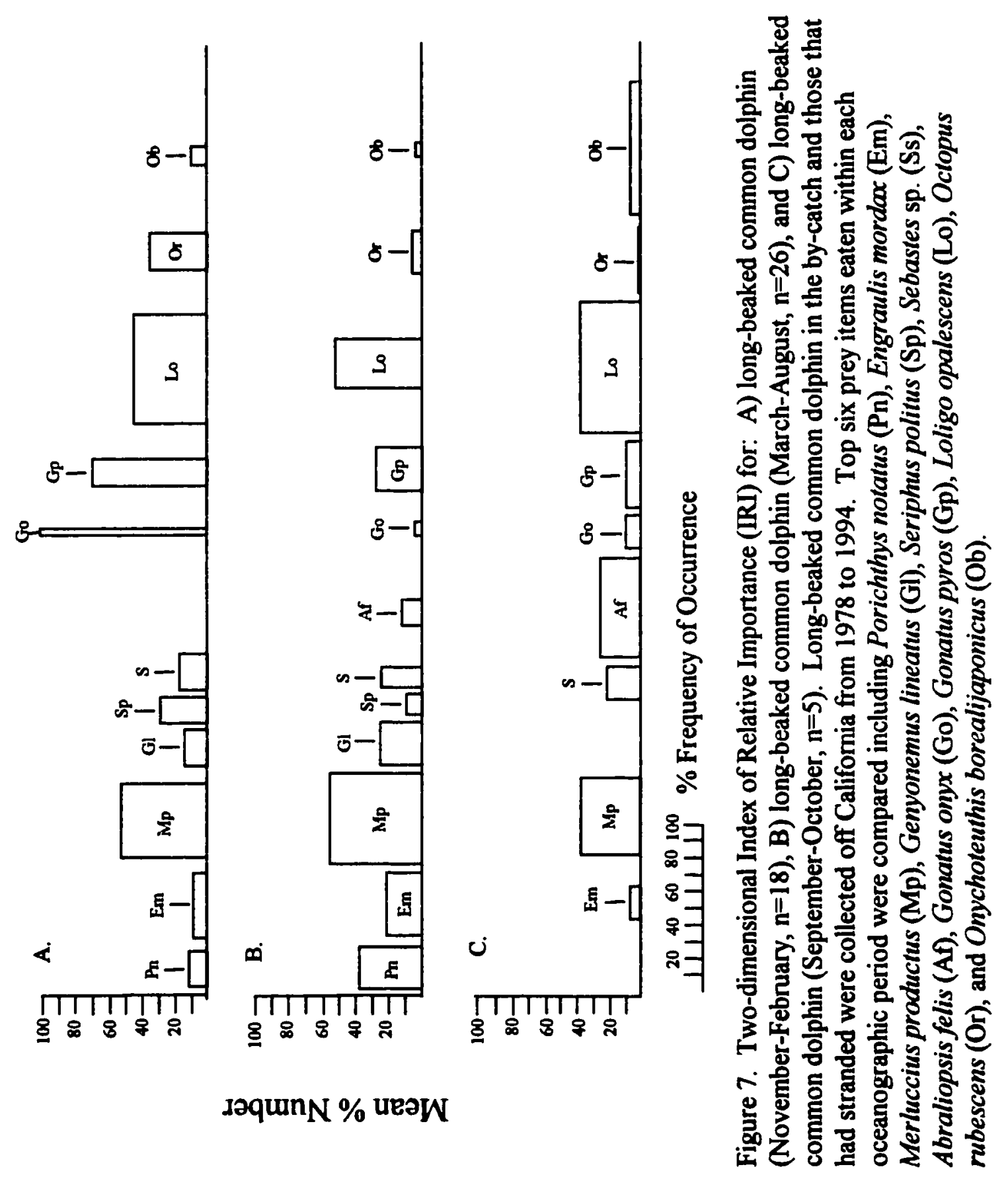



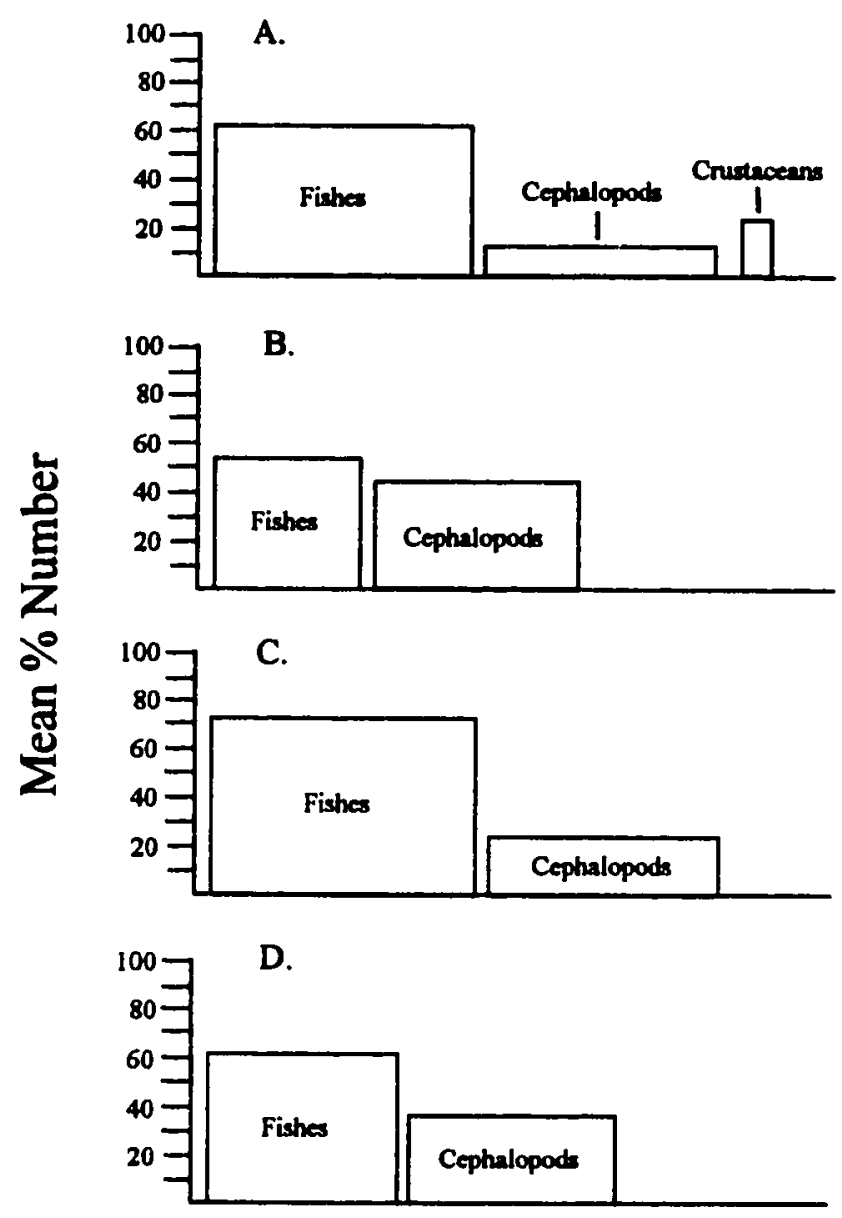

$\perp^{20} \perp^{40} \perp^{60} \perp^{80} \perp^{100} \perp^{\prime} \%$ Frequency of Occurrence

Figure 8. Two-dimensional Index of Relative Importance (IRI) for: A) short-beaked common dolphin in the by-catch, B) short-beaked common dolphin that had stranded, C) long-beaked common dolphin in the by-catch, and D) long-beaked common dolphin that had stranded. Short-beaked (Delphimus delphis) and long-beaked (Delphimus capensis) common dolphin in the by-catch and those that had stranded were collected off California from 1975 to 1994. 
Appendix 1. Specimens obtained of short-beaked (Delphimus delphis) and long-beaked (Delphimus capensis) common dolphins from the Natural History Museum of Los Angeles County (LACM), Southwest Fisheries Science Center (SWFSC), Long Marine Laboratory (LML), and Moss Landing Marine Laboratories (MLML). Data recorded included sex $(M=$ male, $F=$ female), date animal was collected, and type of occurrence (whether animals were in the by-catch or had stranded).

\begin{tabular}{|c|c|c|c|c|c|}
\hline Source & Specimen Number & Species & Sex & Collection Date & Occurrence \\
\hline LACM & 84143 & D. delphis & $\mathbf{M}$ & 11-Feb-75 & Stranding \\
\hline LACM & 54179 & D. delphis & $\mathbf{M}$ & 6-Feb-78 & Stranding \\
\hline LACM & JEH1014 & D. delphis & $\mathbf{F}$ & 27-Jan-80 & Stranding \\
\hline LACM & 84078 & D. delphis & $\mathbf{M}$ & 4-Dec-80 & Stranding \\
\hline LACM & 72496 & D. delphis & $\mathbf{M}$ & 28-Feb-83 & By-catch \\
\hline LACM & 84134 & D. delphis & $\mathbf{F}$ & 26-Dec-87 & Stranding \\
\hline LACM & 84129 & D. delphis & $\mathbf{F}$ & 10-May-88 & By-catch \\
\hline LACM & 84225 & D. delphis & $\mathbf{M}$ & 9-Feb-89 & Stranding \\
\hline LACM & 84222 & D. delphis & $\mathbf{F}$ & 17-Feb-89 & Stranding \\
\hline LACM & 86038 & D. delphis & $\mathbf{M}$ & 15-Apr-89 & Stranding \\
\hline LACM & 86053 & D. delphis & $\mathbf{M}$ & 17-Sep-89 & Stranding \\
\hline LACM & 84279 & D. delphis & $\mathbf{F}$ & 25-Dec-89 & Stranding \\
\hline LACM & 84255 & D. delphis & $\mathbf{F}$ & 18-Jan-90 & Stranding \\
\hline LACM & 85954 & D. delphis & $\mathbf{M}$ & $17-$ Feb-90 & Stranding \\
\hline LACM & 85955 & D. delphis & $\mathbf{M}$ & 24-Aug-90 & Stranding \\
\hline SWFSCLACM & VLD056/86067 & D. delphis & $\mathbf{M}$ & 1-Jan-91 & By-catch \\
\hline SWFSC/LACM & RSR098/86068 & D. delphis & $\mathbf{M}$ & 9-Jan-91 & By-catch \\
\hline LACM & 86000 & D. delphis & $\mathbf{M}$ & 17-Mar-91 & Stranding \\
\hline SWFSC/LACM & TGS001/86069 & D. delphis & $\mathbf{M}$ & $17-J u l-91$ & By-catch \\
\hline SWFSCILACM & EKL004/86070 & D. delphis & $\mathbf{M}$ & 28-Jul-91 & By-catch \\
\hline SWFSC $/ \mathrm{ACM}$ & CMS013/86071 & D. delphis & $\mathbf{M}$ & 17-Aug-91 & By-catch \\
\hline SWFSC/LACM & CMSO14/86072 & D. delphis & $\mathbf{M}$ & 17-Aug-91 & By-catch \\
\hline SWFSC/LACM & CSM015/86073 & D. delphis & $\mathbf{M}$ & 17-Aug-91 & By-catch \\
\hline SWFSC/LACM & CMSO16/86074 & D. delphis & $\mathbf{M}$ & 17-Aug-91 & By-catch \\
\hline SWFSC/LACM & RXJ007/86075 & D. delphis & $\mathbf{F}$ & 30-Aug-91 & By-catch \\
\hline LACM & 86051 & D. delphis & $\mathbf{M}$ & 16-Sep-91 & By-catch \\
\hline SWFSC $/ L A C M$ & RPM014/86078 & D. delphis & $\mathbf{F}$ & 19-Sep-91 & By-catch \\
\hline SWFSC/LACM & RPM015/86079 & D. delphis & $\mathbf{M}$ & 19-Sep-91 & By-catch \\
\hline LACM & 86048 & D. delphis & $\mathbf{M}$ & 26-Sep-91 & By-catch \\
\hline SWFSC/LACM & WXC019/86081 & D. delphis & $\mathbf{M}$ & 6-Dec-91 & By-catch \\
\hline SWFSC $/ L A C M$ & NRM014/86083 & D. delphis & $\mathbf{F}$ & 13-Dec-91 & By-catch \\
\hline SWFSC/LACM & JGK049/91280 & D. delphis & $\mathbf{M}$ & 14-Dec-91 & By-catch \\
\hline SWFSC $/$ ACM & MSK045/86084 & D. delphis & $\mathbf{M}$ & 16-Dec-91 & By-catch \\
\hline SWFSC $/ L A C M$ & NRM023/86085 & D. delphis & $\mathbf{F}$ & 17-Dec-91 & By-catch \\
\hline SWFSC $/$ LACM & MSK049/91389 & D. delphis & $\mathbf{M}$ & 18-Dec-91 & By-catch \\
\hline LACM & 86056 & D. delphis & $\mathbf{F}$ & 6-Jan-92 & Stranding \\
\hline SWFSC $/$ ACM & JGK050/86086 & D. delphis & $\mathbf{M}$ & $11-\operatorname{Jan}-92$ & By-catch \\
\hline
\end{tabular}


Appendix 1 (con't).

\begin{tabular}{|c|c|c|c|c|c|}
\hline Source & Specimen Number & Species & Sex & Collection Date & Occurrence \\
\hline SWFSCILACM & MSK052/86087 & D. delphis & $\mathbf{M}$ & 14-Jan-92 & By-catch \\
\hline SWFSC/LACM & JFB033/91753 & D. delphis & $\mathbf{M}$ & 27-Sep-92 & By-catch \\
\hline SWFSCILACM & JFB048/91379 & D. delphis & $\mathbf{M}$ & 4-Oct-92 & By-catch \\
\hline SWFSCILACM & BJD0006/91374 & D. delphis & $\mathbf{F}$ & $10-0 c t-92$ & By-catch \\
\hline SWFSC/LACM & BJD0017/88926 & D. delphis & $\mathbf{F}$ & $16-0 \mathrm{ct}-92$ & By-catch \\
\hline LACM & 88920 & D. delphis & $\mathbf{M}$ & 4-Dec-92 & By-catch \\
\hline LACM & 88930 & D. delphis & $\mathbf{F}$ & 12-Dec-92 & Stranding \\
\hline LML & DD7May93 & D. delphis & $\mathbf{M}$ & 7-May-93 & Stranding \\
\hline LACM & 54463 & D. capensis & $\mathbf{F}$ & 31-Jan-78 & Stranding \\
\hline LACM & 72284 & D. capensis & $\mathbf{M}$ & 7-May-80 & Stranding \\
\hline LACM & 72286 & D. capensis & $\mathbf{F}$ & 24-Nov-80 & Stranding \\
\hline LACM & 72289 & D. capensis & $\mathbf{F}$ & 14-Feb-82 & Stranding \\
\hline LACM & 72500 & D. capensis & $\mathbf{M}$ & 1-Aug-83 & Stranding \\
\hline LACM & 84083 & D. capensis & $\mathbf{F}$ & 25-Apr-86 & Stranding \\
\hline LACM & 84071 & D. capensis & $\mathbf{M}$ & 7-Aug-86 & Stranding \\
\hline LACM & 84258 & D. capensis & $\mathbf{F}$ & 13-Dec-86 & By-catch \\
\hline LACM & 84021 & D. capensis & $\mathbf{F}$ & 2-Feb-87 & By-catch \\
\hline LACM & 84092 & D. capensis & $\mathbf{F}$ & 15-Feb-87 & By-catch \\
\hline LACM & 84040 & D. capensis & $\mathbf{F}$ & 4-Mar-87 & By-catch \\
\hline LACM & 84130 & D. capensis & F & 12-Nov-87 & By-catch \\
\hline LACM & 84121 & D. capensis & F & 20-May-88 & By-catch \\
\hline LACM & 84100 & D. capensis & $\mathbf{F}$ & 26-May-88 & By-catch \\
\hline LACM & 84125 & D. capensis & $\mathbf{F}$ & 14-Jul-88 & Stranding \\
\hline LACM & 84135 & D. capensis & $\mathbf{F}$ & 24-Sep-88 & Stranding \\
\hline LACM & 84233 & D. capensis & $\mathbf{M}$ & $31-0 c t-88$ & Stranding \\
\hline LACM & 84185 & D. capensis & $\mathbf{M}$ & $31-0 c t-88$ & Stranding \\
\hline LACM & 84239 & D. capensis & $\mathbf{M}$ & 18-Nov-88 & Stranding \\
\hline LACM & 84184 & D. capensis & $\mathbf{M}$ & 8-Dec-88 & By-catch \\
\hline LACM & 84221 & D. capensis & $\mathbf{M}$ & 12-Feb-89 & Stranding \\
\hline LACM & 84223 & D. capensis & $\mathbf{F}$ & 4-Mar-89 & Stranding \\
\hline LACM & 84220 & D. capensis & $\mathbf{M}$ & 14-Apr-89 & Stranding \\
\hline LACM & 84236 & D. capensis & $\mathbf{F}$ & 27-May-89 & Stranding \\
\hline LACM & 84278 & D. capensis & $\mathbf{M}$ & $14-0 c t-89$ & Stranding \\
\hline LACM & 84256 & D. capensis & $\mathbf{M}$ & 7-Jan-90 & By-catch \\
\hline LACM & 84281 & D. capensis & $\mathbf{F}$ & 1-Mar-90 & Stranding \\
\hline LACM & 84254 & D. capensis & $\mathbf{M}$ & 15-Mar-90 & Stranding \\
\hline LACM & 85953 & D. capensis & $\mathbf{M}$ & 24-Sep-90 & By-catch \\
\hline LACM & 85998 & D. capensis & $\mathbf{M}$ & $1-F e b-91$ & Stranding \\
\hline LACM & 85995 & D. capensis & $\mathbf{M}$ & 8-May-91 & Stranding \\
\hline LACM & 86007 & D. capensis & $\mathbf{F}$ & 8-Jun-91 & Stranding \\
\hline LACM & 88902 & D. capensis & $\mathbf{M}$ & 23-Dec-91 & Stranding \\
\hline SWFSC $L A C M$ & WXC036/88908 & D. capensis & $\mathbf{F}$ & 2-Jun-92 & By-catch \\
\hline SWFSC/LACM & WXC037/91367 & D. capensis & $\mathbf{F}$ & 4-Jun-92 & By-catch \\
\hline
\end{tabular}


Appendix 1 (con't).

\begin{tabular}{|c|c|c|c|c|c|}
\hline Source & Specimen Number & Species & Sex & Collection Date & Occurrence \\
\hline SWFSC $/$ ACM & ASP010/91370 & D. capensis & F & 26-Aug-92 & By-catch \\
\hline SWFSC/LACM & ASP011/91371 & D. capensis & $\mathbf{F}$ & 26-Aug-92 & By-catch \\
\hline LACM & 88955 & D. capensis & $\mathbf{F}$ & 4-Nov-92 & Stranding \\
\hline MLML & MMIs0 & D. capensis & $\mathbf{F}$ & $10-$ Nov-92 & Stranding \\
\hline LACM & 88988 & D. capensis & $\mathbf{F}$ & 13-Jan-93 & Stranding \\
\hline MLML & MMl40 & D. capensis & $\mathbf{F}$ & 8-Feb-93 & Stranding \\
\hline LACM & 91325 & D. capensis & F & 29-Apr-93 & Stranding \\
\hline MLML & MM188 & D. capensis & F & 23-Jan-94 & Stranding \\
\hline MLML & MM193 & D. capensis & $\mathbf{M}$ & 4-Mar-94 & Stranding \\
\hline MLMI & MM192 & D. capensis & $\mathbf{M}$ & 5-Mar-94 & Stranding \\
\hline MLML & MZH0003 & D. capensis & $\mathbf{M}$ & 7-Apr-94 & Stranding \\
\hline MLML & 88997 & D. capensis & $\mathbf{M}$ & 29-Apr-94 & Stranding \\
\hline MLML & 88998 & D. capensis & $\mathbf{M}$ & 29-Apr-94 & Stranding \\
\hline MLML & MM198 & D. capensis & $\mathbf{F}$ & 1-Jun-94 & Stranding \\
\hline
\end{tabular}


Appendix 2. Mean percentage number $(\% \mathrm{~N})$, standard deviation (SD), percentage frequency of occurrence (\%FO), Index of Relative Importance (IRI), and percentage IRI for prey species identified from stomach contents of short-beaked common dolphin in the by-catch ( $\mathrm{n}=28)$, collected off California from 1983 to 1992.

\begin{tabular}{|c|c|c|c|c|c|}
\hline Prey Species & Mean \%N & SD & $\% \mathrm{FO}$ & IRI & \%IRI \\
\hline $\begin{array}{l}\text { FISHES } \\
\text { Argentinidxe }\end{array}$ & 62.52 & 15.24 & 96.43 & 6028.80 & 81.18 \\
\hline Argentina sialis & 1.26 & 1.90 & 10.71 & 13.49 & 0.12 \\
\hline $\begin{array}{l}\text { Nonsenia candida" } \\
\text { Buthylagidue }\end{array}$ & 0.78 & 1.45 & 28.57 & 22.28 & 0.19 \\
\hline Leuroglossus stilbius & 7.95 & 13.41 & 42.86 & 340.74 & 2.98 \\
\hline $\begin{array}{l}\text { Unidentifiable bathylagidae } \\
\text { Batrachoididae }\end{array}$ & 10.65 & 19.10 & 35.71 & 380.31 & 3.33 \\
\hline $\begin{array}{l}\text { Porichihys notatus } \\
\text { Carangidae }\end{array}$ & 13.79 & 0.00 & 3.57 & 49.23 & 0.43 \\
\hline $\begin{array}{l}\text { Trachurus symmetricus: } \\
\text { Centrolophidae }\end{array}$ & 5.30 & 6.70 & $10.7 !$ & 56.76 & 0.50 \\
\hline $\begin{array}{l}\text { Jcichthys lockingtont } \\
\text { Clupeidac }\end{array}$ & 0.10 & 0.00 & 3.57 & 0.36 & 0.00 \\
\hline $\begin{array}{l}\text { Sardinops sagax } \\
\text { Engrauliduc }\end{array}$ & 8.00 & 0.00 & 3.57 & 28.56 & 0.25 \\
\hline $\begin{array}{l}\text { Engraulis mordax } \\
\text { Gonontomatidec }\end{array}$ & 21.15 & 25.04 & 10.71 & 226.52 & 1.98 \\
\hline $\begin{array}{l}\text { Ichthyococcus irregularis" } \\
\text { Meiamphajdac }\end{array}$ & 3.38 & 3.54 & 7.14 & 24.13 & 0.21 \\
\hline $\begin{array}{l}\text { Melamphaes lugubris" } \\
\text { Scopelogadus mizolepis }\end{array}$ & $\begin{array}{l}1.30 \\
0.56\end{array}$ & $\begin{array}{l}1.21 \\
0.27\end{array}$ & $\begin{array}{l}21.43 \\
10.71\end{array}$ & $\begin{array}{c}27.86 \\
6.00\end{array}$ & $\begin{array}{l}0.24 \\
0.05\end{array}$ \\
\hline $\begin{array}{l}\text { Merlucciidec } \\
\text { Merluccius productus } \\
\text { Myctophidue }\end{array}$ & 15.57 & 26.27 & 25.00 & 389.25 & 3.41 \\
\hline Ceratoscopelus townsendi & 10.54 & 9.03 & 71.43 & 752.87 & 6.59 \\
\hline Diaphus thera & 9.20 & 10.37 & 50.00 & 460.00 & 4.02 \\
\hline Electrona rissoi" & 1.02 & 1.06 & 7.14 & 7.28 & 0.06 \\
\hline Lampadena urophaos & 1.55 & 1.55 & 21.43 & 33.22 & 0.29 \\
\hline Lampanyctus ritteri" & 12.55 & 14.65 & 57.14 & 717.11 & 6.27 \\
\hline Lampanyctus c.f. L. jordani" & 0.25 & 0.00 & 3.57 & 0.89 & 0.01 \\
\hline c.f. Myciophum nitidulum" & 0.88 & 0.00 & 3.57 & 3.14 & 0.03 \\
\hline Noroscopelus resplendens" & 0.44 & 0.29 & 10.71 & 4.71 & 0.04 \\
\hline Parviluxingens: & 0.40 & 0.30 & 21.43 & 8.57 & 0.07 \\
\hline Protomyctophum crockeri* & 0.71 & 0.80 & 17.86 & 12.68 & 0.11 \\
\hline Stenobrachius leucopsarus & 10.41 & 13.96 & 64.29 & 669.26 & 5.86 \\
\hline Symbolophorus californiensis" & 9.90 & 13.15 & 60.71 & 601.03 & 5.26 \\
\hline Tarletonbeania cremularis & 0.76 & 0.49 & 17.86 & 13.57 & 0.12 \\
\hline Triphorurus mexicamus* & 8.30 & 9.95 & 50.00 & 415.00 & 3.63 \\
\hline $\begin{array}{l}\text { Unidentifiable myctophidac } \\
\text { Ophidiidee }\end{array}$ & 7.69 & 6.86 & 57.14 & 439.41 & 3.84 \\
\hline $\begin{array}{l}\text { Chilara taylori } \\
\text { Paralepididee }\end{array}$ & 0.98 & 1.65 & 14.29 & 14.00 & 0.12 \\
\hline Lestidium ringens" & 0.54 & 0.65 & 14.29 & 7.72 & 0.07 \\
\hline $\begin{array}{l}\text { Paralepis atlantica* } \\
\text { Sciacnidece }\end{array}$ & 0.20 & 0.01 & 7.14 & 1.43 & 0.01 \\
\hline $\begin{array}{l}\text { Genponemus linearus } \\
\text { Scombereacidace }\end{array}$ & 93.33 & 0.00 & 3.57 & 333.19 & 2.92 \\
\hline Cololabis saira & 4.18 & 5.17 & 35.71 & 149.27 & 1.31 \\
\hline
\end{tabular}


Appendix 2 (con't).

\begin{tabular}{|c|c|c|c|c|c|}
\hline Prey Species & Mean $\% \mathrm{~N}$ & SD & $\% \mathrm{FO}$ & $\mathbf{R I}$ & \%IRI \\
\hline \multicolumn{6}{|l|}{ Scombridec } \\
\hline $\begin{array}{l}\text { Scomber japonicus } \\
\text { Scorpeenidae }\end{array}$ & 20.24 & 30.30 & 21.43 & 433.74 & 3.79 \\
\hline $\begin{array}{l}\text { Sebastes sp." } \\
\text { Stemoptychidee }\end{array}$ & 2.84 & 3.74 & 7.14 & 20.28 & 0.18 \\
\hline $\begin{array}{l}\text { Argyropelecus sp." } \\
\text { Truchipleridue }\end{array}$ & 0.82 & 0.00 & 3.57 & 2.93 & 0.03 \\
\hline $\begin{array}{l}\text { Trachipterus sp." } \\
\text { Zoarcidee }\end{array}$ & 0.38 & 0.00 & 3.57 & 1.36 & 0.01 \\
\hline Unidentified Zoarcidae sp. C* & 0.28 & 0.00 & 3.57 & 1.00 & 0.01 \\
\hline Unidentifiable teleoat & 7.91 & 10.06 & 17.86 & 141.27 & 1.24 \\
\hline $\begin{array}{l}\text { CEPHALOPODS } \\
\text { Chiroleuthidae }\end{array}$ & \multicolumn{3}{|c|}{ Chiroteuthidae } & 1132.20 & 15.25 \\
\hline $\begin{array}{l}\text { Chiroteuthis calyx } \\
\text { Cranchiider }\end{array}$ & 2.22 & 2.36 & 46.43 & 103.07 & 0.90 \\
\hline Cranchia seabra* & 2.01 & 2.42 & 35.71 & 71.78 & 0.63 \\
\hline $\begin{array}{l}\text { Leachia sp." } \\
\text { Enoploteuthidac }\end{array}$ & 2.88 & 4.02 & 17.86 & 51.44 & 0.45 \\
\hline Abraliopsis felis & 21.55 & 20.79 & 78.57 & 1693.18 & 14.81 \\
\hline c.f. Abraliopsis felis & 5.52 & 0.00 & 3.57 & 19.71 & 0.17 \\
\hline $\begin{array}{l}\text { Abraliopsis c.f. A. falco } \\
\text { Gonutidac }\end{array}$ & 0.38 & 0.00 & 3.57 & 1.36 & 0.01 \\
\hline Gonatopsis borealis & 3.56 & 2.88 & 50.00 & 178.00 & 1.56 \\
\hline c.f. Gonatopsis borealls & 4.83 & 0.00 & 3.57 & 17.24 & 0.15 \\
\hline Gonatus berryi & 1.21 & 1.54 & 39.29 & 47.54 & 0.42 \\
\hline Gonatus onyx & 1.46 & 1.31 & 10.71 & 15.64 & 0.14 \\
\hline Gonarus pyros * & 2.63 & 4.57 & 57.14 & 150.28 & 1.31 \\
\hline $\begin{array}{l}\text { Unidentifiable Gonatus sp. } \\
\text { Histioceuthidec }\end{array}$ & 0.38 & 0.00 & 3.57 & 1.36 & 0.01 \\
\hline Histroleuthis dofeint" & 0.59 & 0.00 & 3.57 & 2.11 & 0.02 \\
\hline $\begin{array}{l}\text { Histioleuthis hereropsis } \\
\text { Loliginidac }\end{array}$ & 1.07 & 0.76 & 32.14 & 34.39 & 0.30 \\
\hline $\begin{array}{l}\text { Loligo opalescens } \\
\text { Octopoleuthidac }\end{array}$ & 2.66 & 3.54 & 21.43 & 57.00 & 0.50 \\
\hline $\begin{array}{l}\text { Octopoteuthis deletron " } \\
\text { Onycholeuthidue }\end{array}$ & 0.44 & 0.29 & 32.14 & 14.14 & 0.12 \\
\hline Moroteuthis robustus" & 0.74 & 0.64 & 10.71 & 7.93 & 0.07 \\
\hline Onychoreuthis borealijaponicus * & 3.90 & 4.82 & 57.14 & 222.85 & 1.95 \\
\hline Octopodidese & & & & & \\
\hline Octopus rubescens" & 0.56 & 0.00 & 3.57 & 2.00 & 0.02 \\
\hline Unidentifiable decapod & 1.48 & 1.51 & 32.14 & 47.57 & 0.42 \\
\hline $\begin{array}{l}\text { CRUSTACEANS } \\
\text { Sergestidae }\end{array}$ & 24.80 & 57.64 & 10.71 & 265.61 & 3.58 \\
\hline Sergestes similis * & 99.47 & 0.00 & 3.57 & 355.11 & 3.11 \\
\hline Unidentifiable decapod crustacean & 17.95 & 21.48 & 7.14 & 128.16 & 1.12 \\
\hline
\end{tabular}


Appendix 3. Mean percentage number $(\% \mathrm{~N})$, standard deviation (SD), percentage frequency of occurrence (\%FO), Index of Relative Importance (IRI), and percentage IRI for prey species identified from stomach contents of short-beaked common dolphin that had stranded ( $n=17)$, collected off California from 1975 to 1993.

\begin{tabular}{|c|c|c|c|c|c|}
\hline Prey Species & Mean \%N & SD & $\% \mathrm{FO}$ & IRI & \%IRI \\
\hline FISHES & 54.70 & 14.43 & $\mathbf{5 2 . 9 4}$ & 2895.82 & 45.53 \\
\hline \multicolumn{6}{|l|}{ Atherinidec } \\
\hline $\begin{array}{l}\text { Alherinops affinis* } \\
\text { Buthylagidne }\end{array}$ & 8.33 & 0.00 & 5.88 & 48.98 & 0.36 \\
\hline $\begin{array}{l}\text { Unidentifiable bathylagidae } \\
\text { Batrechoididae }\end{array}$ & 7.69 & 0.00 & 5.88 & 45.22 & 0.34 \\
\hline $\begin{array}{l}\text { Porichehys notatus } \\
\text { Bothidae }\end{array}$ & 20.35 & 20.17 & 17.65 & 359.18 & 2.67 \\
\hline $\begin{array}{l}\text { Citharichthys stigmaeus" } \\
\text { Clupeidae }\end{array}$ & 4.17 & 0.00 & 5.88 & 24.52 & 0.18 \\
\hline $\begin{array}{l}\text { Sardinops sagax } \\
\text { Engraulidac }\end{array}$ & 20.00 & 0.00 & 5.88 & 117.60 & 0.87 \\
\hline $\begin{array}{l}\text { Engraulis mordax } \\
\text { Merluaciidac }\end{array}$ & 25.15 & 26.82 & 17.65 & 443.90 & 3.30 \\
\hline $\begin{array}{l}\text { Merluccius productus } \\
\text { Myctophidae }\end{array}$ & 60.88 & 34.04 & 41.18 & 2507.04 & 18.62 \\
\hline Ceratoscopelus rownsendi & 0.31 & 0.00 & 5.88 & 1.82 & 0.01 \\
\hline Diaphus theta & 24.17 & 22.39 & 11.76 & 284.24 & 2.11 \\
\hline Lampanycrus ritteri* & 2.56 & 0.00 & 5.88 & 15.05 & 0.11 \\
\hline Mycrophum nitidulum" & 1.23 & 0.00 & 5.88 & 7.23 & 0.05 \\
\hline Stenobrachius leucopsarus & 1.99 & 1.37 & 11.76 & 18.70 & 0.14 \\
\hline Triphoturus mexicanus* & 11.54 & 0.00 & 5.88 & 67.86 & 0.50 \\
\hline Unidentifiable myctophidace & 20.19 & 26.29 & 17.65 & 356.35 & 2.65 \\
\hline Paralepididac & & & & & \\
\hline $\begin{array}{l}\text { Lestidium ringens" } \\
\text { Sciacnidac }\end{array}$ & 1.28 & 0.00 & 5.88 & 7.53 & 0.06 \\
\hline Genyonemus lineatus & 9.55 & 12.21 & 11.76 & 112.31 & 0.83 \\
\hline $\begin{array}{l}\text { Seriphus polirus } \\
\text { Scombridee }\end{array}$ & 4.48 & 5.45 & 11.76 & 52.68 & 0.39 \\
\hline Scomber japonicus & 16.67 & 0.00 & 5.88 & 98.02 & 0.73 \\
\hline Unidentifiable teleost & 24.85 & 12.00 & 11.76 & 292.24 & 2.17 \\
\hline CEPHALOPODS & 45.30 & 18.16 & 76.47 & 3463.09 & 54.47 \\
\hline Chiroteuthidace & & & & & \\
\hline $\begin{array}{l}\text { Chiroteuthis calyx } \\
\text { Gonulidac }\end{array}$ & 50.16 & 70.49 & 11.76 & 589.88 & 4.38 \\
\hline Gonatopsis borealis & 43.81 & 49.00 & 17.65 & 773.25 & 5.74 \\
\hline Gonatus berryi & 9.17 & 5.89 & 11.76 & 107.84 & 0.80 \\
\hline Gonams onyx & 15.72 & 8.08 & 11.76 & 184.87 & 1.37 \\
\hline Gonarus pyros" & 26.03 & 18.56 & 29.41 & 765.54 & 5.69 \\
\hline $\begin{array}{l}\text { Unidentifiable Gonasus sp. } \\
\text { Loliginidee }\end{array}$ & 8.87 & 8.67 & 11.76 & 104.31 & 0.77 \\
\hline $\begin{array}{l}\text { Loligo opalescens } \\
\text { Octopoleuthidne }\end{array}$ & 44.79 & 43.48 & 52.94 & 2371.18 & 17.61 \\
\hline $\begin{array}{l}\text { Octopoteuthis deletron" } \\
\text { Onycholeuthidue }\end{array}$ & 9.65 & 6.57 & 11.76 & 113.48 & 0.84 \\
\hline $\begin{array}{l}\text { Onychoteuthis borealijaponicus" } \\
\text { Octopodidne }\end{array}$ & 5.36 & 4.03 & 17.65 & 94.60 & 0.70 \\
\hline Octopus nubescens* & 0.91 & 0.00 & 5.88 & 5.35 & 0.04 \\
\hline
\end{tabular}


Appendix 3 (con't).

Prey Species

Mean \%N

SD

$\%$ FO

IRI

\%IRI

Ocythoidece

Ocythoe nuberculata*

5.00

0.00

5.88

29.40

0.22

"previously unreported prey species 
Appendix 4. Mean percentage number $(\% N)$, standard deviation (SD), percentage frequency of occurrence (\%FO), Index of Relative Importance (IRI), and percentage IRI for prey species identified from stomach contents of long-beaked common dolphin in the by-catch ( $n=14)$, collected off California from 1986 to 1992.

\begin{tabular}{|c|c|c|c|c|c|}
\hline Prey Species & Mean \%N & SD & $\% \mathrm{FO}$ & IRI & \%IRI \\
\hline FISHES & 73.12 & 9.47 & 100.00 & 7312.00 & 76.04 \\
\hline \multicolumn{6}{|l|}{ Argentinidue } \\
\hline Argentina sialis & 17.50 & 0.00 & 7.14 & 124.95 & 1.02 \\
\hline Nansenia candida" & 1.68 & 0.00 & 7.14 & 12.00 & 0.10 \\
\hline \multicolumn{6}{|l|}{ Bathylagidec } \\
\hline Leuroglossus stilbius & 3.45 & 1.06 & 14.29 & 49.30 & 0.40 \\
\hline Unidentifiable bathylagidac & 9.40 & 10.92 & 14.29 & 134.33 & 1.09 \\
\hline \multicolumn{6}{|l|}{ Batrachoididae } \\
\hline $\begin{array}{l}\text { Porlchthys notatus } \\
\text { Bothidue }\end{array}$ & 13.57 & 12.37 & 28.57 & 387.69 & 3.15 \\
\hline $\begin{array}{l}\text { Citharichthys stigmaeus" } \\
\text { Carangidae }\end{array}$ & 1.88 & 0.00 & 7.14 & 13.42 & 0.11 \\
\hline Trachurus symmetricus" & 0.63 & 0.00 & 7.14 & 4.50 & 0.04 \\
\hline \multicolumn{6}{|l|}{ Centrolophidee } \\
\hline $\begin{array}{l}\text { Icichrhys lockingroni } \\
\text { Clupeidac }\end{array}$ & 0.84 & 0.00 & 7.14 & 6.00 & 0.06 \\
\hline $\begin{array}{l}\text { Sardinops sagax } \\
\text { Embiotocidae }\end{array}$ & 6.67 & 0.00 & 7.14 & 47.62 & 0.39 \\
\hline $\begin{array}{l}\text { Cymatogaster aggregata* } \\
\text { Engraulidace }\end{array}$ & 1.49 & 1.19 & 14.29 & 21.29 & 0.17 \\
\hline \multicolumn{5}{|l|}{ Melamphuidue } & 2.10 \\
\hline Melomphaes lugubris* & 1.68 & 0.00 & 7.14 & 12.00 & 0.10 \\
\hline Unidentifiable melumphneidae & 3.49 & 0.00 & 7.14 & 24.92 & 0.20 \\
\hline \multicolumn{6}{|l|}{ Merlucciiduc } \\
\hline $\begin{array}{l}\text { Merluccius productus } \\
\text { Myctophidac }\end{array}$ & 48.02 & 33.19 & 50.00 & 2401.00 & 19.51 \\
\hline Ceratoscopelus townsendi & 14.30 & 10.75 & 21.43 & 306.45 & 2.49 \\
\hline Diaphus theta & 14.40 & 9.73 & 28.57 & 411.41 & 3.34 \\
\hline Lampadena urophaos & 2.52 & 0.00 & 7.14 & 17.99 & 0.15 \\
\hline Lampanyctus ritkeri" & 13.25 & 16.34 & 28.57 & 378.55 & 3.08 \\
\hline Protomyctophum crockeri" & 0.84 & 0.00 & 7.14 & 6.00 & 0.05 \\
\hline Sienobrachius leucopsarus & 5.88 & 0.00 & 7.14 & 41.98 & 0.34 \\
\hline Symbolophorus californiensis" & 2.07 & 1.82 & 14.29 & 29.58 & 0.24 \\
\hline Tarletombeania cremularis & 3.60 & 0.00 & 7.14 & 25.70 & 0.21 \\
\hline Unidentifiable myctophidue & 3.87 & 2.86 & 21.43 & 82.93 & 0.67 \\
\hline \multicolumn{6}{|l|}{ Ophichthidee } \\
\hline Unidentified ophichuhidee sp. $A^{*}$ & 2.17 & 0.00 & 7.14 & 15.49 & 0.13 \\
\hline Unidentified ophichlhidre sp. B* & 2.17 & 0.00 & 7.14 & 15.49 & 0.13 \\
\hline \multicolumn{6}{|l|}{ Ophidiidec } \\
\hline Chilara taylori & 2.18 & 2.16 & 21.43 & 46.72 & 0.38 \\
\hline \multicolumn{6}{|l|}{ Scisenidae } \\
\hline Genyonemus lineatus & 26.64 & 22.21 & 21.43 & 570.90 & 4.64 \\
\hline Seriphus polims & 6.51 & 10.91 & 28.57 & 185.99 & 1.51 \\
\hline Unidentifiable sciaenidac & 12.77 & 0.79 & 14.29 & 182.48 & 1.48 \\
\hline \multicolumn{6}{|l|}{ Scombridue } \\
\hline Scomber japonicus & 1.16 & 0.00 & 7.14 & 8.28 & 0.07 \\
\hline \multicolumn{6}{|l|}{ Scorpaenidue } \\
\hline Sebastes sp." & 19.67 & 27.66 & 21.43 & 421.53 & 3.43 \\
\hline
\end{tabular}


Appendix 4 (con't).

Prey Species

Zoercidne

Unidentified zourcides sp. A*

Unidentified zourcidec sp. $B^{*}$

Unidentifiable zoarcidac

Unidentifiable teleod

\section{CEPHALOPODS}

Cranchiidac

Cranchia scabra*

Leachia sp."

Enoploteuthidne

Abraliopsis felis

Gonutidue

Gonatopsis borealis

Gonatus berryi

Gonatus pyros"

Unidentified Gonarus sp.

Histioteuthidese

Histioteuthis heteropsis

Loliginidee

Loligo opalescens

Octopoteuthide

Octoporeuthis deletron*

Omychoteuthidae

Onychoreuthis borealijaponicus"

Sepiolidue

Rossia pacifica"

Octopodidee

Octopus rubescens"

Unidentifiable decapod

Mean \%N

SD

\%FO

IRI

\%IRI

\begin{tabular}{|c|c|c|c|c|}
\hline 2.78 & 0.00 & 7.14 & 19.85 & 0.16 \\
\hline 1.39 & 0.00 & 7.14 & 9.92 & 0.08 \\
\hline 11.25 & 0.00 & 7.14 & 80.33 & 0.65 \\
\hline 5.09 & 5.24 & 21.43 & 109.08 & 0.89 \\
\hline 26.88 & 12.29 & 85.71 & 2303.88 & 23.96 \\
\hline 4.70 & 0.49 & 14.29 & 67.16 & 0.55 \\
\hline 1.13 & 0.93 & 21.43 & 24.22 & 0.20 \\
\hline 31.34 & 23.22 & 21.43 & 671.62 & 5.46 \\
\hline 2.78 & 3.54 & 42.86 & 119.15 & 0.97 \\
\hline 1.31 & 0.00 & 7.14 & 9.35 & 0.08 \\
\hline 4.25 & 3.55 & 35.71 & 151.77 & 1.23 \\
\hline 0.39 & 0.00 & 7.14 & 2.78 & 0.02 \\
\hline 1.94 & 0.00 & 7.14 & 13.85 & 0.11 \\
\hline 40.02 & 32.24 & 57.14 & 2286.74 & 18.59 \\
\hline 1.84 & 0.96 & 14.29 & 26.29 & 0.21 \\
\hline 2.38 & 1.80 & 21.43 & 51.00 & 0.41 \\
\hline 1.25 & 0.00 & 7.14 & 8.93 & 0.07 \\
\hline 4.06 & 4.90 & 21.43 & 87.01 & 0.71 \\
\hline 2.17 & 0.00 & 7.14 & 15.49 & 0.13 \\
\hline
\end{tabular}


Appendix 5. Mean percentage number $(\% \mathrm{~N})$, standard deviation (SD), percentage frequency of occurrence (\%FO), Index of Relative Importance (IRI), and percentage IRI for prey species identified from stomach contents of long-beaked common dolphin that had stranded $(n=35)$, collected off California from 1978 to 1994.

\begin{tabular}{|c|c|c|c|c|c|}
\hline Prey Species & Mean \%N & SD & $\% \mathrm{FO}$ & IRI & $\%$ IRI \\
\hline $\begin{array}{l}\text { FISHES } \\
\text { Argentinidae }\end{array}$ & 62.82 & 14.85 & 71.43 & 487.23 & 61.01 \\
\hline $\begin{array}{l}\text { Argentina sialis } \\
\text { Atherinidue }\end{array}$ & 1.52 & 0.00 & 2.86 & 4.35 & 0.03 \\
\hline $\begin{array}{l}\text { Atherinops affinis* } \\
\text { Batrachoididee }\end{array}$ & 1.92 & 0.00 & 2.86 & 5.49 & 0.04 \\
\hline $\begin{array}{l}\text { Porichthys myriaster" } \\
\text { Porichthys notarus } \\
\text { Bothidec }\end{array}$ & $\begin{array}{c}2.03 \\
26.12\end{array}$ & $\begin{array}{c}0.00 \\
17.91\end{array}$ & $\begin{array}{c}2.86 \\
20.00\end{array}$ & $\begin{array}{c}5.81 \\
522.40\end{array}$ & $\begin{array}{l}0.05 \\
4.06\end{array}$ \\
\hline Citharichthys stigmaeus" & 0.56 & 0.00 & 2.86 & 1.60 & 0.01 \\
\hline $\begin{array}{l}\text { Unidentifiable Citharichthys sp. } \\
\text { Clupeidae }\end{array}$ & 0.51 & 0.00 & 2.86 & 1.46 & 0.01 \\
\hline $\begin{array}{l}\text { Sardimops sagax } \\
\text { Coutidac }\end{array}$ & 34.38 & 0.00 & 2.86 & 98.33 & 0.76 \\
\hline $\begin{array}{l}\text { Radulinus asprellus" } \\
\text { Embiolocidac }\end{array}$ & 0.51 & 0.00 & 2.86 & 1.46 & 0.01 \\
\hline $\begin{array}{l}\text { Cymatogaster aggregata } \\
\text { Engraulidac }\end{array}$ & 0.56 & 0.00 & 2.86 & 1.60 & 0.01 \\
\hline $\begin{array}{l}\text { Engraulis mordax } \\
\text { Merlucciidae }\end{array}$ & 21.01 & 29.91 & 34.29 & 720.43 & 5.60 \\
\hline $\begin{array}{l}\text { Merluccius productus } \\
\text { Myctophidae }\end{array}$ & $\$ 1.91$ & 31.88 & 48.57 & 2521.27 & 19.59 \\
\hline Lampanyctus ritteri* & 5.79 & 0.00 & 2.86 & 16.56 & 0.13 \\
\hline Stenobrachius leucopsarus & 7.58 & 1.29 & 5.71 & 43.28 & 0.34 \\
\hline Symbolophorus californiensis* & 0.39 & 0.00 & 2.86 & 1.12 & 0.01 \\
\hline $\begin{array}{l}\text { Unidentifiable myctophidace } \\
\text { Ophidiidue }\end{array}$ & 1.16 & 0.00 & 2.86 & 3.32 & 0.03 \\
\hline Chilara taylori & 2.50 & 2.03 & 8.57 & 21.43 & 0.17 \\
\hline Otophidium serippsi* & 1.92 & 0.00 & 2.86 & 5.49 & 0.04 \\
\hline $\begin{array}{l}\text { Unidentifiable ophidiidac } \\
\text { Pleuronectidac }\end{array}$ & 1.52 & 0.00 & 2.86 & 4.35 & 0.03 \\
\hline $\begin{array}{l}\text { Lyopsetta exilis" } \\
\text { Sciaenidue }\end{array}$ & 29.37 & 39.39 & 5.71 & 167.70 & 1.30 \\
\hline Cheilotrema sanurmum & 3.33 & 0.00 & 2.86 & 9.52 & 0.07 \\
\hline Genyonemus lineatus & 17.27 & 33.73 & 22.86 & 394.79 & 3.07 \\
\hline Seriphus politus & 46.19 & 55.89 & 5.71 & 263.74 & 2.05 \\
\hline $\begin{array}{l}\text { Unidentifiable sciaenidac } \\
\text { Scombridac }\end{array}$ & 17.59 & 24.08 & 5.71 & 100.44 & 0.78 \\
\hline $\begin{array}{l}\text { Scomber japonicus } \\
\text { Scompueniduc }\end{array}$ & 5.00 & 0.00 & 2.86 & 14.30 & 0.11 \\
\hline $\begin{array}{c}\text { Sebastes sp: } \\
\text { Unidentifiable teloost }\end{array}$ & $\begin{array}{l}17.45 \\
9.64\end{array}$ & $\begin{array}{l}25.35 \\
10.78\end{array}$ & $\begin{array}{l}14.29 \\
37.14\end{array}$ & $\begin{array}{l}249.36 \\
358.03\end{array}$ & $\begin{array}{l}1.94 \\
2.78\end{array}$ \\
\hline $\begin{array}{l}\text { CEPHALOPODS } \\
\text { Chiroteuthides }\end{array}$ & 37.18 & 19.85 & 77.14 & 2686.07 & 38.99 \\
\hline $\begin{array}{l}\text { Chirotewthis calyx } \\
\text { Enoploteuthidae }\end{array}$ & 7.07 & 11.20 & 8.57 & 60.59 & 0.47 \\
\hline Abraliopsisfelis & 5.63 & 2.99 & 11.43 & 64.35 & 0.50 \\
\hline
\end{tabular}


Appendix 5 (con't).

\begin{tabular}{|c|c|c|c|c|c|}
\hline Prey Species & Mean \%N & SD & $\% \mathrm{FO}$ & IRI & \%IRI \\
\hline \multicolumn{6}{|l|}{ Gontidece } \\
\hline Gonatopsis borealis & 4.96 & 5.84 & 5.71 & 28.32 & 0.22 \\
\hline Gonaris berryi & 0.77 & 0.00 & 2.86 & 2.20 & 0.02 \\
\hline Gonahus onyx & 28.55 & 47.72 & 11.43 & 326.33 & 2.54 \\
\hline Gonatus pyros" & 56.78 & 35.69 & 20.00 & 1135.60 & 8.83 \\
\hline Unidentifiable gonatidae & 4.50 & 0.00 & 2.86 & 12.87 & 0.10 \\
\hline \multicolumn{6}{|l|}{ Loliginidae } \\
\hline $\begin{array}{l}\text { Loligo opalescens } \\
\text { Onycholeuthidse }\end{array}$ & 49.94 & 37.74 & 45.71 & 2282.76 & 17.74 \\
\hline $\begin{array}{l}\text { Onychotewthis borealijaponicus" } \\
\text { Octopodidae }\end{array}$ & 8.38 & 9.19 & 14.29 & 119.75 & 0.93 \\
\hline $\begin{array}{l}\text { Octopus rubescens" } \\
\text { Ocythoidue }\end{array}$ & 14.96 & 30.55 & 28.57 & 427.41 & 3.32 \\
\hline Ocynhoe tuberculata" & 0.56 & 0.00 & 2.86 & 1.60 & 0.01 \\
\hline "previously unreported prey species & & & & & \\
\hline
\end{tabular}

